\title{
Air quality monitoring in communities of the Canadian Arctic during the high shipping season with a focus on local and marine pollution
}

\author{
A. A. Aliabadi ${ }^{1}$, R. M. Staebler ${ }^{1}$, and S. Sharma ${ }^{2}$ \\ ${ }^{1}$ Atmospheric Processes Research Section, Environment Canada, \\ 4905 Dufferin Street, Toronto, ON M3H 5T4, Canada \\ ${ }^{2}$ Climate Chemistry Measurements and Research Section, Environment \\ Canada, 4905 Dufferin Street, Toronto, ON M3H 5T4, Canada
}

Correspondence to: A. A. Aliabadi (aliabadi@aaa-scientists.com)

Received: 2 October 2014 - Published in Atmos. Chem. Phys. Discuss.: 28 November 2014

Revised: 26 January 2015 - Accepted: 28 January 2015 - Published: 9 March 2015

\begin{abstract}
The Canadian Arctic has experienced decreasing sea ice extent and increasing shipping activity in recent decades. While there are economic incentives to develop resources in the north, there are environmental concerns that increasing marine traffic will contribute to declining air quality in northern communities. In an effort to characterize the relative impact of shipping on air quality in the north, two monitoring stations have been installed in Cape Dorset and Resolute, Nunavut, and have been operational since 1 June 2013. The impact of shipping and other sources of emissions on $\mathrm{NO}_{\mathrm{x}}, \mathrm{O}_{3}, \mathrm{SO}_{2}, \mathrm{BC}$, and $\mathrm{PM}_{2.5}$ pollution have been characterized for the 2013 shipping season from 1 June to 1 November. In addition, a high-resolution Air Quality Health Index (AQHI) for both sites was computed. Shipping consistently increased $\mathrm{O}_{3}$ mixing ratio and $\mathrm{PM}_{2.5}$ concentration. The $90 \%$ confidence interval for mean difference in $\mathrm{O}_{3}$ mixing ratio between ship- and no shipinfluenced air masses were up to $4.6-4.7 \mathrm{ppb}$ and $2.5-2.7 \mathrm{ppb}$ for Cape Dorset and Resolute, respectively. The same intervals for $\mathrm{PM}_{2.5}$ concentrations were up to $1.8-1.9 \mu \mathrm{g} \mathrm{m}^{-3}$ and $0.5-0.6 \mu \mathrm{g} \mathrm{m}^{-3}$. Ship-influenced air masses consistently exhibited an increase of 0.1 to 0.3 in the high-resolution AQHI compared to no ship-influenced air masses. Trajectory cluster analysis in combination with ship traffic tracking provided an estimated range for percent ship contribution to $\mathrm{NO}_{\mathrm{x}}, \mathrm{O}_{3}$, $\mathrm{SO}_{2}$, and $\mathrm{PM}_{2.5}$ that were 12.9-17.5\%, 16.2-18.1\%, 16.9$18.3 \%$, and $19.5-31.7 \%$ for Cape Dorset and $1.0-7.2 \%$, $2.9-4.8 \%, 5.5-10.0 \%$, and $6.5-7.2 \%$ for Resolute during
\end{abstract}

the 2013 shipping season. Additional measurements in Resolute suggested that percent ship contribution to black carbon was $4.3-9.8 \%$ and that black carbon constituted $1.3-9.7 \%$ of total $\mathrm{PM}_{2.5}$ mass in ship plumes. Continued air quality monitoring in the above sites for future shipping seasons will improve the statistics in our analysis and characterize repeating seasonal patterns in air quality due to shipping, local pollution, and long-range transport.

\section{Introduction}

The Arctic is a highly uncertain environment on the planet in terms of climate change. The year-to-year and regional variability for most environmental indicators are linked to a persistent warming trend that began more than 30 years ago. Of such indicators, the Arctic sea ice extent annual minimum in September 2013 was almost $20 \%$ less than the 1981-2010 average (Jeffries et al., 2013). The warming trend and receding sea ice will potentially increase marine accessibility in the region. Climate model projections of future sea ice reductions in the Arctic and other considerations have been used to speculate significant increase in ship navigability by mid-century, to the extent that new optimal navigation routes, such as the Northwest Passage, the Northern Sea Route, and the Arctic Bridge, may be accessible to various classes of ice-strengthened ships during the months of July to September (Stephenson et al., 2011; Smith and Stephenson, 2013). 
Arctic sea ice in Canada has also retreated in recent decades with strong negative trends in the Hudson and Baffin bays (Tivy et al., 2011; Derksen et al., 2012). Vessel transit within the Vessel Traffic Reporting Arctic Canada Traffic Zone (NORDREG) has been observed since 1990. Statistically significant increases in traffic have already been observed within NORDREG on both monthly and annual timescales, coinciding with declines in sea ice area (for first-year ice, multiyear ice, and total ice). For example, the monthly traffic increase was reported to be as high as 22 vessels per decade in July for all vessel classes combined (Pizzolato et al., 2014). The decreasing ice and increasing marine navigability will likely enhance resource development in the region. This has the potential to disturb the fragile ecosystem and hurt the aboriginal way of life. In addition, due to current low levels of shipping traffic in the Canadian Arctic, any increase in marine activity will represent a relatively significant change (Brigham et al., 2009). These considerations warrant the need for the close examination of the impact of shipping on air quality in the Canadian Arctic.

\subsection{Long-range transport and large time-scale variability of surface pollutants}

Long-range transport, seasonal, and annual variability of surface pollutants in the Arctic have been studied in some detail. Black carbon (BC) is of particular interest due to significant light absorption and reduction of surface albedo in the Arctic, particularly during the summer (Law and Stohl, 2007; Quinn et al., 2008). Sharma et al. (2006) reported that equivalent black carbon (EBC) concentrations in Barrow and Alert were $40 \%$ higher during the positive phase of North Atlantic Oscillation than during the negative phase. Trajectory analyses revealed source contributions with influence from Siberia/Europe for Alert and Siberia/Pacific Asia for Barrow. In addition, the 15-year period from 1989 to 2003 revealed a downward trend in EBC by as much as $54 \%$ in Alert and $27 \%$ in Barrow, likely due to reduced industrial activity in the former USSR. An inter-model assessment by Shindell et al. (2008) suggests that North America and Europe each contribute about $40 \%$ of total $\mathrm{BC}$ deposition to Greenland, with about $20 \%$ from East Asia. Elsewhere in the Arctic, the total BC deposition is dominated by European emissions. A word of caution is that model uncertainties in aerosol physical and chemical processes, particularly removal, remain high at the present time, so any model predictions of aerosol concentrations in the Arctic are questionable.

Trends in surface ozone mixing ratios in the Arctic are complicated due to a multitude of chemical and physical processes including long-range transport, titration, photochemistry, and halogen chemistry. However, regarding surface levels, models suggest that mixing ratios are expected to increase due to the influence of distance sources by less than 8 ppb from 2000 to 2100 (Granier et al., 2006). Cana- dian sites have shown a decrease in annual tropospheric ozone in the 1980s but an increase since the 1990s (Law and Stohl, 2007). Inter-model comparisons reveal that North America contributes the most to Arctic ozone pollution via a response most strongly linked to $\mathrm{NO}_{\mathrm{x}}$ emissions (Shindell et al., 2008). Ground-based studies show that warming trends and $\mathrm{NO}_{\mathrm{x}}$ precursors have led to enhanced photochemical ozone production in the Arctic (Law and Stohl, 2007). In addition to annual variations, recent measurements in Barrow, Alert, and Zeppelinfjellet indicated a seasonal trend with ozone levels increasing from summer lows to spring highs (Helmig et al., 2007; Shindell et al., 2008).

Regarding other pollutants, measurements by Novelli et al. (1998) identified seasonal cycles for carbon monoxide (CO) with summer lows and spring highs. Inter-model comparisons suggest a significant European contribution to $\mathrm{CO}$ pollution in the Arctic, accompanied by North America and east Asia (Shindell et al., 2008). Similar seasonal trends have been observed for sulfates in Alert (Sirois and Barrie, 1999). Shindell et al. (2008) also suggested a higher contribution of sulfates in the Arctic by European emissions. It is expected that long-term $\mathrm{NO}_{\mathrm{x}}$ and $\mathrm{SO}_{2}$ trends will be closely linked to ozone and sulfate trends, respectively, because they are considered precursors for these pollutants.

\subsection{Local transport and short time-scale variability of surface pollutants}

A study by Stohl et al. (2013) suggested that chemistry transport or climate chemistry models have deficiencies when estimating surface $\mathrm{BC}$ in the Arctic, partly attributed to shortcomings in current emission data sets for local residential combustion and flaring. In addition, as mentioned earlier, model deposition rates for aerosols in the Arctic are not accurate, which adds to uncertainties in surface BC concentrations. The ECLIPSE (Evaluating the CLimate and air quality ImPacts of Short-livEd pollutants) data set estimated flaring to contribute less than $3 \%$ of global BC emissions, while in the Arctic it contributes $66 \%$. Using the FLEXPART Lagrangian particle dispersion model, Stohl et al. (2013) demonstrated that Arctic flaring contributes $42 \%$ to the annual mean BC surface concentrations. They demonstrated that accounting for daily and monthly variations in Arctic flaring and residential emissions improves simulations for surface $\mathrm{BC}$ concentrations, in agreement with $\mathrm{BC}$ measurements in six Arctic stations. Aircraft and international shipping emissions have been ignored in their study. Browse et al. (2013) studied recently compiled Arctic shipping emission inventories for 2004 and 2050 (Corbett et al., 2010a) together with a global aerosol model to quantify the contribution of future Arctic shipping to high-latitude BC deposition. BC emissions from shipping were found to contribute $0.3 \%$ to the total BC mass deposited north of $60^{\circ} \mathrm{N}$ in 2004 and $0.7 \%$ in a 2050 high-growth scenario. The shipping impact was not uniform over the entire Arctic. For example, the deposi- 
tion was $10-15 \%$ in 2050 over Greenland. It was suggested that natural emission variability from boreal wildfires and anthropogenic emissions in lower latitudes have the greatest influence on BC levels in the Arctic. As far as long-term in-Arctic ship emission inventory estimates are concerned, Corbett et al. (2010a) have suggested that BC emissions will increase by a factor of 3 to 5.3 by 2050 under business-asusual and high-growth scenarios. Observational campaigns by Eckhardt et al. (2013) have identified the impact of cruise ship emissions in the vicinity of Kongsfjord on surface EBC in Ny Ålesund and Zepplin mountain in Svalbard, Norway. Over an analysis period from 2003 to 2011, it was estimated that EBC concentrations increased by $11 \%$ when cruise ships with more than 50 passengers were in the area.

Granier et al. (2006) studied ozone pollution from future ship traffic in the Arctic northern passages using MOZART4 (Model for OZone And Related chemical Tracers) and ECMWF (European Center for Medium-Range Weather Forecasts). They assumed that 12.5 to $25 \%$ of global shipping emissions will occur in the Arctic by 2050 and uniformly distributed the emission factors along the northern passages. They suggested that summer surface ozone mixing ratios could be enhanced by up to $40 \mathrm{ppb}$ in the decades ahead due to ship operations through the northern passages. Measurements by Eckhardt et al. (2013) suggested that, on average, ozone concentrations dropped by 5\% (2003-2011) due to immediate titration when there were ships in the vicinity of Svalbard, Norway; however, the authors admit that over larger distances and longer residence times, ozone could be enhanced in the ship plumes. Summertime surface ozone mixing ratios have yet to be better understood in the Arctic (Law and Stohl, 2007). As far as natural processes are concerned, Arctic ozone depletion episodes (ODEs) are linked to conversion of inert halide salt ions (e.g., $\mathrm{Br}^{-}$) into reactive halogen species such as $\mathrm{Br}$ atoms that deplete ozone in the boundary layer. ODEs last for hours to weeks at a time and occur mostly in the spring season, coinciding with the polar sunrise (Helmig et al., 2007; Seabrook et al., 2011), so their occurrence will mostly interfere with anthropogenic sources of pollution in the spring.

Regarding other pollutants, Granier et al. (2006) used the same methodology described earlier to predict an increase of up to $10 \mathrm{ppb}$ in $\mathrm{NO}_{\mathrm{x}}$ concentrations in the northern passages by 2050 due to shipping activity. Measurements by Eckhardt et al. (2013) suggested that on average $\mathrm{SO}_{2}$ concentrations increased by $18 \%$ (2003-2011) when there were ships in the vicinity of Svalbard, Norway. Corbett et al. (2010a) have provided in-Arctic ship emission inventory estimates for $\mathrm{NO}_{\mathrm{x}}$, $\mathrm{CO}, \mathrm{SO}_{\mathrm{x}}$, and PM by mid-century according to business-asusual and high-growth scenarios. The emissions for $\mathrm{NO}_{\mathrm{x}}$ and $\mathrm{CO}$ are suggested to increase by factors of 2.2 to 3.8 and 2.9 to 5.2, while the inventories for $\mathrm{SO}_{\mathrm{x}}$ and $\mathrm{PM}$ may decline by factors of 0.6 to 1.0 and 0.6 to 1.4 due to stringent regulations limiting sulfur content in ship fuels and other emissionreduction controls.
While long-range transport, seasonal, and annual variations in the Arctic air quality have been researched in considerable depth, there is still work to be done to characterize local sources and transport of pollutants (e.g., from ships in the Arctic) and short-term variability in air quality caused by anthropogenic sources. Particularly during the summer, the Arctic dome reduces continental transfer of pollutants to the region so that the relative contribution of local sources of emissions become higher (Law and Stohl, 2007).

\subsection{Controls and regulations for shipping emissions}

It has been reported that $3.3 \%$ of global $\mathrm{CO}_{2}$ emissions, 5 to $8 \%$ of global anthropogenic $\mathrm{SO}_{2}$ emissions, and $2 \%$ of global $\mathrm{BC}$ emissions are produced by shipping (Lack and Corbett, 2012). The International Convention for the Prevention of Pollution from Ships (MARPOL) within the International Maritime Organization (IMO) sets the limits for air pollutants released by ships. The regulations are sometimes annexed by more stringent limits for emission control areas (ECAs) such as the one in North America (NA-ECA). NAECA came into force in August 2012 (Bulletin, 2013). There is currently no ECA for Canadian waters north of $60^{\circ}$ latitude. In Canada, the domestic regulations on marine emissions are Vessel Pollution and Dangerous Chemicals Regulations, Canadian Environmental Protection Act, and Clean Air Regulatory Agenda, all of which ensure compliance with NA-ECA and IMO regulations.

Sulfur emissions from ships are of particular interest since, in addition to $\mathrm{SO}_{2}$, they give rise to primary and secondary particulate matter pollution (Lack and Corbett, 2012; Jalkanen et al., 2012). It has been suggested that lower sulfur content in ship fuels reduces particulate matter and BC emission factors (Petzold et al., 2011; Lack et al., 2011). It has also been suggested that lower-sulfur fuels reduce the formation of cloud condensation nuclei (Petzold et al., 2010) and particulate matter size (Lack et al., 2011) in the ship plumes. Sulfur content in ship fuels has been required by MARPOL to reduce to $3.50 \%$ in 2012 and $0.5 \%$ in 2020 globally and to $1.00 \%$ in 2011 and $0.1 \%$ in 2015 within the NA-ECA (IMO, 2009; Bulletin, 2013). $\mathrm{NO}_{\mathrm{x}}$ emissions have also been regulated by the IMO based on ship engine speed, age, and size. Strict controls on $\mathrm{NO}_{\mathrm{x}}$ emissions within the NA-ECA place a release limit of 2.0 to $17.0 \mathrm{~g} \mathrm{kWh}^{-1}$ based on engine type and size (Bulletin, 2013). $\mathrm{CO}_{2}$ emissions are to be reduced through the first mandatory global greenhouse gas regulation by the IMO. Development of international regulatory measures in place to manage $\mathrm{BC}$ emissions from ship engines is a hot topic at the present (Corbett et al., 2010b).

Various on-board control measures have also been suggested. Ship speed and engine load are important contributors to ship emission factors. It has been observed that speed reduction results in better fuel economy and, hence, lower $\mathrm{CO}_{2}$ emissions due to reduced drag on the ship hulls (Jalkanen et al., 2012; Lack and Corbett, 2012). It has also been ob- 
served that lower speeds reduce particulate matter, $\mathrm{BC}, \mathrm{NO}_{\mathrm{x}}$ emission factors, and particulate matter size (Cappa et al., 2014). On the other hand, reduced engine loads do not necessarily result in reduced emission factors for all species. For example, organic carbon and carbon monoxide (CO) actually increase with reduced loads (Jalkanen et al., 2012). Other technologies such as slide valves, water-in-fuel emulsion, diesel particulate filters, emulsified fuel, and seawater scrubbing have been proposed to reduce emission factors for various pollutants (Corbett et al., 2010b; Lack and Corbett, 2012). It is essential to realize that no technology reduces all emission factors simultaneously. Many remedies result in reduced fuel economy (higher $\mathrm{CO}_{2}$ emissions) due to running auxiliary pumps and other equipment, while others reduce some emission factors at the expense of increasing the others (Corbett et al., 2010b). The detailed discussions are beyond the scope of this study.

\subsection{Research objectives}

Increasing shipping traffic in the Canadian Arctic necessitates the understanding of its impacts on air quality, particularly relative to other local sources. This is vital in order to properly regulate marine traffic in the Canadian Arctic for future decades. Most recent works in this area remain speculative in nature, solely relying on models or bulk inventory emission analyses. While there has been some observational success in characterizing emission factors at the "source" (i.e., ship stacks or ship plume interception campaigns) (Jalkanen et al., 2009, 2012; Petzold et al., 2008, 2010; Lack et al., 2011; Cappa et al., 2014), the authors have only found limited studies (Eckhardt et al., 2013; Zhan et al., 2014) attempting to measure Arctic air pollution due to ship emissions at "receptor" sites, which is an alternative indicator of shipping emission impacts on air quality. These studies are confined in time duration or spatial extent over which shipping in the Arctic must be assessed as a whole.

To measure pollution from shipping vs. other local sources in the Canadian Arctic, two monitoring stations were set up as receptors for $\mathrm{NO}, \mathrm{NO}_{2}, \mathrm{NO}_{\mathrm{x}}, \mathrm{O}_{3}, \mathrm{SO}_{2}$, and $\mathrm{PM}_{2.5}$. The first monitoring station resides in Cape Dorset, Nunavut $\left(64.22998^{\circ} \mathrm{N}, 76.53031^{\circ} \mathrm{W}\right)$, and faces the Arctic Bridge near Hudson Strait; the second monitoring station resides in Resolute, Nunavut $\left(74.70634^{\circ} \mathrm{N}, 94.96883^{\circ} \mathrm{W}\right)$ and faces the Northwest Passage near Barrow Strait (Fig. 1). Both monitoring stations have been operational since 1 June 2013 and provide pollutant levels at a 1 min time resolution. The Resolute site is also equipped with particle size distribution and equivalent black carbon measurements equipment. Shipping traffic and air mass trajectories in the Canadian Arctic have been studied in detail for a period of 5 months (1 June 20131 November 2013), covering the complete 2013 shipping season. An analysis is performed to apportion air pollution into shipping and other local sources of emissions.

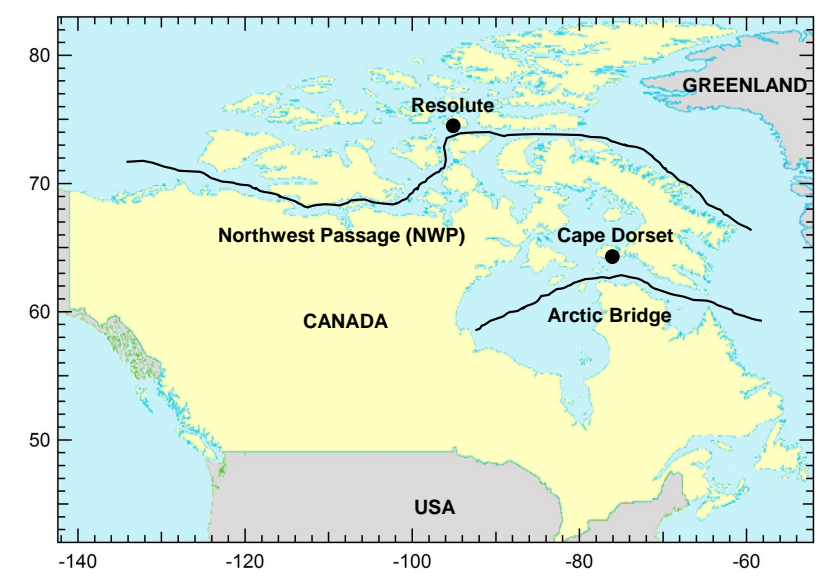

Figure 1. Site locations for air quality monitoring stations in the Canadian Arctic; monitoring station in Cape Dorset facing the Arctic Bridge near Hudson Strait; monitoring station in Resolute facing the Northwest Passage near Barrow Strait.

\section{Methods}

\subsection{Vessel traffic data set}

Vessel traffic information was acquired from the Canadian Coast Guard, available for Canadian government agencies and research institutions at www.innav.gc.ca. The data set is one of the most comprehensive of its kind and provides vessel type, name, flag, call sign, and Lloyds registration numbers. In addition, the repository provides GPS position and activity reports. It is not mandatory for Vessels entering NORDREG to report their activity and location; however, there is more than $98 \%$ compliance in reporting due to advantages accompanied by participation such as icebreaker support (Rompkey and Cochrane, 2008). Participating ships are required to communicate at least daily while in NORDREG, although actual reporting is more frequent.

As an alternative to the Canadian Coast Guard data set, the Automatic Identification System could have been used for ship traffic tracking with greater temporal and spatial resolution but possibly fewer ships identified. This technology has been successfully used over the European Arctic in tracking ships (Winther et al., 2014). For the purpose of our analysis, however, we believe that the Canadian Coast Guard data set is sufficient since, given the low resolution and accuracy associated with air mass trajectory models, these data sets are not expected to give different results.

It is common to encounter location entries in the database that are harbor or community names instead of latitude and longitude coordinates. A lookup table has been developed and appended to convert location names into coordinates accordingly. Vessel reporting frequency is neither uniform in time nor homogeneous in space. Ships communicate with a range of time resolutions from minutes to hours. They also overreport activity in strategic locations such as the Barrow 
Strait and underreport in non-critical locations (e.g., the middle of Hudson Bay). To reconstruct high-resolution, uniform, and homogeneous vessel coordinates, the positions were interpolated, subject to spatial and temporal filters, a concept successfully implemented in previous studies (Jalkanen et al., 2009, 2012). The temporal filter only allowed interpolation for time gaps less than $48 \mathrm{~h}$, and the spatial filter only allowed interpolation for locations physically possible to travel by ships, given a maximum ship speed. A novel algorithm was developed to move interpolated points from land to the closest location on the sea by a displacement perpendicular to the interpolation line. This resulted in shortest reroutes for ships that were also consistent with established traffic routes.

A total of 27921 ship reports were processed to create the vessel traffic data set with a 1 min time resolution for the entire analysis period. In total, 109 ships (with Lloyd registration numbers) were active in the Canadian Arctic during the 2013 shipping season. These ships were merchant, passenger, cargo, fishing, tug, cruise, coast guard icebreaker, and other types ranging from $\sim 2000 \mathrm{HP}$ tugs to $\sim 30000 \mathrm{HP}$ coast guard icebreakers.

\subsection{Air quality measurements}

\subsubsection{Gaseous pollution and $\mathrm{PM}_{2.5}$ measurements}

The monitoring stations in both locations consist of a commercially available integrated air quality package (airpointer ${ }^{\circledR}$, manufactured by recordum ${ }^{\circledR}$ Messtechnik $\mathrm{GmbH}$ in Austria, hardware v. 2, software v. 1.9.7). The assembly includes $\mathrm{PM}_{2.5}, \mathrm{O}_{3}, \mathrm{NO}_{\mathrm{x}}$, and $\mathrm{SO}_{2}$ analyzers, a weather station to measure wind direction/speed, temperature, relative humidity, pressure, and an on-board computer system for remote control and data logging. The $\mathrm{PM}_{2.5}$ analyzer (SHARP 5030) operates based on light-scattering nephelometry and beta absorption. The $\mathrm{O}_{3}, \mathrm{NO}_{\mathrm{x}}$, and $\mathrm{SO}_{2}$ analyzers operate based on UV photometry, chemiluminescence, and UV fluorescent light scattering, respectively. The wind sensor is a 2-D sonic anemometer manufactured by Vaisala (WXT520).

There are about 45 airpointers ${ }^{\circledR}$ deployed in Canada today that operate for the federal government (e.g., Environment Canada and Health Canada), provincial governments, cities, universities, and industry. The airpointer ${ }^{\circledR}$ was approved by TÜV Rheinland Immissionsschutz und Energiesysteme GmbH (Germany) in January 2009 as compliant with DIN EN 14211, DIN EN 14212, DIN EN 14625, and DIN EN 14626 Standards (TÜV, 2009).

As per specification sheets, the lower detection limits (LDLs) for $\mathrm{PM}_{2.5}, \mathrm{O}_{3}, \mathrm{NO}_{\mathrm{x}}$, and $\mathrm{SO}_{2}$ analyzers are < $1 \mu \mathrm{g} \mathrm{m}^{-3}, 0.5 \mathrm{ppb}, 0.4 \mathrm{ppb}$, and $0.4 \mathrm{ppb}$, respectively, for 1 min integration times. The monitoring stations are set up with the capability of internal calibration for zero and span for the gas analyzers on a daily basis. We performed an in-
Table 1. Precision for gas pollutant measurements at lower detection limit, based on daily internal zero calibration.

\begin{tabular}{lccc}
\hline Site & $\begin{array}{c}\mathrm{NO}_{\mathrm{x}}(\mathrm{ppb}) \\
\text { precision }\end{array}$ & $\begin{array}{c}\mathrm{O}_{3}(\mathrm{ppb}) \\
\text { precision }\end{array}$ & $\begin{array}{c}\mathrm{SO}_{2}(\mathrm{ppb}) \\
\text { precision }\end{array}$ \\
\hline Cape Dorset & \pm 0.327 & \pm 0.808 & \pm 0.104 \\
Resolute & \pm 0.120 & \pm 0.178 & \pm 0.107 \\
\hline
\end{tabular}

house calibration of the gas analyzers against NIST (National Institute of Standards and Technology) secondary standards in April 2013. The daily internal calibration and our own in-house calibration were assimilated in data processing to correct for instrument drift and span variation for the entire analysis period. The focus of the calibration was to reduce "accuracy" errors in the measurements. The calibration involved a two-step process: first, smooth fits to daily zero and span concentrations were determined, and the data were corrected accordingly; second, the data were further corrected by in-house calibration coefficients to ensure the final data set was calibrated against the NIST standards. Our calibration procedure resulted in good "relative" accuracies for gas analyzers since the measurements were corrected for drift on a daily basis. The drift for the $\mathrm{PM}_{2.5}$ analyzer was also checked on a regular basis. Table 1 shows the "precision" (SD) of the daily measurements at zero calibration. Subsequent tabulated measurements of concentration differences are indicated with bold face if they are above the instrument precision.

Some limitations of the airpointer ${ }^{\circledR}$ are worth mentioning. First, the airpointer ${ }^{\circledR}$ is suited for air quality assessment near cities, towns, villages, mines, industrial processes, and monitoring moderate background level variations. However, it is not intended to provide absolute measurements for trace level pollutants in the parts per trillion range, so care must be taken not to report absolute trace levels with high certainty. Our methodology relies on clustering (grouping) of air samples and showing statistically significant differences in their concentration distributions. Second, the measurement of $\mathrm{NO}_{\mathrm{x}}$, which consists of $\mathrm{NO}$ and $\mathrm{NO}_{2}$, is achieved through a switching process using a molybdenum converter. The sampled air is diverted through a converter every $8 \mathrm{~s}$ to convert all of $\mathrm{NO}_{2}$ in the sample to $\mathrm{NO}$, at which point it can be subsequently detected by chemiluminescence. However, the $\mathrm{NO}_{2}$ conversion efficiency may vary according to other nitrogen compounds in the sample gas. As a result, while NO measurements should be accurate, $\mathrm{NO}_{2}$ and $\mathrm{NO}_{\mathrm{x}}$ measurements may be overestimated, particularly when actual $\mathrm{NO}_{2}$ levels are low.

\subsubsection{Particle size distribution and equivalent black carbon measurements}

In Resolute only, particle size and equivalent black carbon (aerosol absorption derived black carbon) measurements 

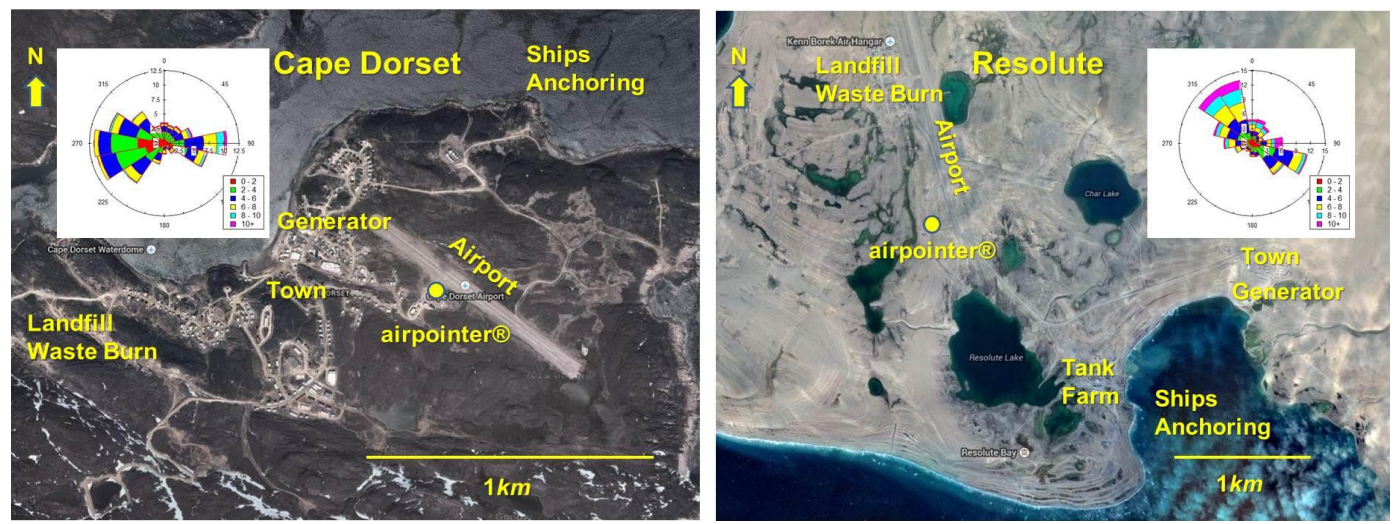

Figure 2. Maps of Cape Dorset and Resolute with monitoring stations; wind roses for $22.5^{\circ}$ sectors with length of each sector indicating frequency $(\%)$ and the color scale indicating wind speed $\left(\mathrm{m} \mathrm{s}^{-1}\right)$; annotations superimposed on Google maps.

were also performed. These measurements were conducted inside a hut located on Environment Canada's Upper Air Building premises, about $100 \mathrm{~m}$ away from the airpointer ${ }^{\circledR}$ location. Stainless-steel tubing $\left(3 / 4^{\prime \prime}\right)$ was used as an inlet, where the air was drawn at a rate of $27 \mathrm{slpm}$ to achieve a size cut of $1 \mu \mathrm{m}$ diameter by using a URL cyclone. Out of 27 , 1 slpm was used by each of the two instruments: a continuous light absorption photometer (CLAP) and a scanning mobility particle sizer (SMPS).

The SMPS (TSI 3034) was used to measure particle size distributions in the 15 to $600 \mathrm{~nm}$ diameter range. The distributions were analyzed with TSI software based on Wang and Flagan (1990) and corrected for mean free path, diffusion losses, and multiple charging. The sizing of the SMPS was compared with $20 \mathrm{~nm}$ and $350 \mathrm{~nm}$ polystyrene latex particles (PSL) on site and found to be within $10 \%$ of the nominal PSL values. A spectrum of particle size distribution was generated every $9 \mathrm{~min}$. The spectra were also averaged corresponding to other simultaneous measurements at the site.

The CLAP (Ogren et al., 2013) was used to measure the light absorption derived equivalent black carbon. The particles were collected on a filter and light transmission through the filter with respect to a clean spot was monitored continuously in the CLAP. It has eight sample spots and two clean reference spots. Solenoids are used to switch to the next sample spot once the filter transmittance reaches the desired limit (typically 0.7). The methodologies of Bond et al. (1999) and Ogren (2010) are applied to the data. The CLAP comes with a small built-in heater that is controlled to a set temperature of, typically, $39^{\circ} \mathrm{C}$ to minimize RH effects during sampling. A mass absorption efficiency (MAE) of $10 \mathrm{~m}^{2} \mathrm{~g}^{-1}$ was used to convert the aerosol light absorption to black carbon mass. There is some uncertainty associated with using this value of MAE, which could be as large as a factor of 2 as was found for a particle soot absorption photometer (Sharma et al., 2004). The LDL for CLAP was $5 \mathrm{ng} \mathrm{m}^{-3}$. For sim- plicity, equivalent black carbon may be referred to as black carbon hereafter in this article.

\subsection{Site selection}

Figure 2 shows the positioning of the monitoring stations relative to the town facilities. For both sites, a location near the airport runway was selected to provide accessibility to power, communication, and service. This also provided a "window" to sample air masses coming from the ocean traffic with minimal contamination from local pollution. When winds are not coming from the ocean, local waste burn, town emissions, and occasionally the airport contribute to pollution measurements. We observed that the winds have preferential directions for both sites, with consequences that will be discussed in the following sections.

A major concern in the applicability of our results to past or future years was whether the weather conditions at the sites for the 2013 shipping season were representative of the recent Arctic climate, particularly for wind patterns, temperatures, and precipitation. Wind patterns govern transport of air pollution, temperature is a key player in atmospheric chemistry and also marine navigability, and precipitation affects wet deposition (removal) of aerosols. We studied the airport climatology of Cape Dorset and Resolute from NAV Canada (Hudson et al., 2001) and compared the wind patterns to our own measurements. Based on frequency plots of wind directions at $22.5^{\circ}$ resolution, NAV Canada reports dominant winds from W, E, and WSW for Cape Dorset and NW and SE for Resolute. The wind rose plots for 2013 in Fig. 2 are consistent with the reported airport climatology.

Monthly average temperatures for each site were obtained from Canada's Historical Climate Data for 1995, 2000, and 2005 (Climate, 2014). Monthly temperatures for this time period from June to October were 2.6 $\pm 1.7,7.6 \pm 2.0,7.2 \pm 1.1$, $1.6 \pm 1.2$, and $-2.5 \pm 1.2^{\circ} \mathrm{C}$ for Cape Dorset and $0.8 \pm 0.9$, $4.2 \pm 0.3,2.1 \pm 1.5,-4.7 \pm 1.7$, and $-14.5 \pm 2.5^{\circ} \mathrm{C}$ for Resolute. Our corresponding average temperature measurements 

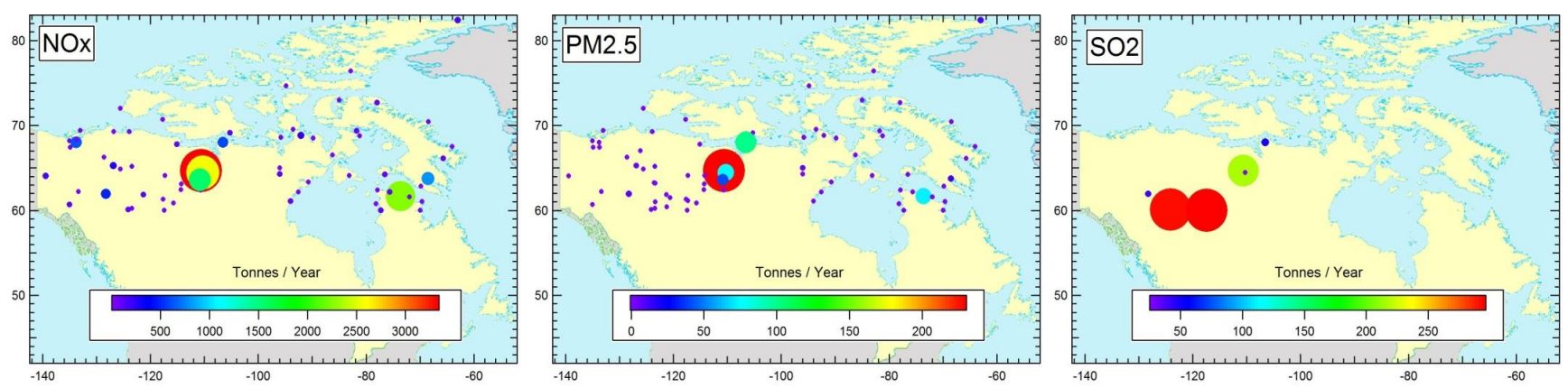

Figure 3. Emission inventories (tonnes $\mathrm{yr}^{-1}$ ) for Canadian facilities above $60^{\circ} \mathrm{N}$ in 2011 for $\mathrm{NO}_{\mathrm{x}}\left(\mathrm{NO}_{2}\right.$ equivalent), $\mathrm{PM}_{2.5}$, and $\mathrm{SO} 2(\mathrm{NPRI}$, 2011).

for 2013 were 3.0, 6.5, 6.1, 0.8, and $-2.0^{\circ} \mathrm{C}$ for Cape Dorset and $-1.3,3.2,0.9,-4.7$, and $-11.1^{\circ} \mathrm{C}$ for Resolute. While all measured temperatures in Cape Dorset fall within SD of the 1995-2005 data, Resolute was colder in some months of 2013.

Monthly average precipitation for each site was also obtained for 1995, 2000, and 2005 (Climate, 2014). The total precipitation from June to October was $26.4 \pm 17.9,37.5 \pm$ 16.2, $53.4 \pm 24.5,43.7 \pm 17.6$, and $55.3 \pm 3.5 \mathrm{~mm}$ for Cape Dorset and 7.1 $\pm 8.2,19.4 \pm 8.1,41.7 \pm 14.3,22.6 \pm 7.3$, and $16.8 \pm 9.6 \mathrm{~mm}$ for Resolute. The average precipitation values for 2013 were 5.1, 42.2, 37.3, 65.6, and $26.5 \mathrm{~mm}$ for Cape Dorset and 14.8, 5.6, 14.4, 1.4, and $12.8 \mathrm{~mm}$ for Resolute. The natural variability of monthly precipitation is high, yet 2013 precipitation does not seem to be consistently above or below 1995-2005 decade averages.

With consideration of wind direction patterns, temperature, and precipitation trends for the 1995-2005 period, we have some confidence that our 2013 results are representative of a typical Arctic year.

\section{4 air mass-trajectory data set}

Accurate source apportionment of surface pollutants in our study required state-of-the-art air mass back trajectory analysis. This was needed to investigate origins of different air masses that arrived at the monitoring stations (55 and $57 \mathrm{~m}$ above sea level for Cape Dorset and Resolute, respectively). HYSPLIT 4 from NOAA's Air Resources Laboratory was used for back trajectory calculations. The available meteorology for HYSPLIT in the Arctic were the "gdas" $1^{\circ}$ spatial and $6 \mathrm{~h}$ time resolution data files (Draxler and Hess, 2010). For each site, the HYSPLIT model produced 3696 trajectories at $1 \mathrm{~h}$ resolution going back in time 5 days. These trajectories were further interpolated to provide $1 \mathrm{~min}$ resolution, in synchronization with air quality and vessel traffic data sets. The model trajectories were compared against field wind direction measurements to provide confidence in the accuracy of the trajectory data set. The model trajectories were also compared against Canadian Meteorological Center tra- jectory model (version 1.6.1). These trajectories were clustered (grouped) in further analysis to identify geographical or ship influence on the chemical signature of the air masses that arrived at the monitoring stations. More sophisticated plume trajectory models, such as those provided by HYSPLIT or FLEXPART, are computationally intensive, requiring immense storage space, and do not fit within the scope of this analysis. Such models are more suitable to study specific pollution episodes corresponding to single ship plume measurements.

\subsection{Emission inventory data set}

To understand the relative magnitude of shipping emissions, it was necessary to have an estimate of the entire emission inventory in the Canadian Arctic. There is limited information on the most current emission inventories in the Canadian Arctic. We have used the National Pollutant Release Inventory (NPRI), available from Environment Canada, for an initial estimate of major sources of emissions from latitudes above $60^{\circ} \mathrm{N}$ (NPRI, 2011). NPRI lists pollutants as generated by sources under two categories: (i) facilities alone and (ii) summaries reported by facilities combined with estimates for other emission sources such as motor vehicles, residential heating, forest fires, and agricultural activities.

The only facilities reported for Cape Dorset and Resolute are the municipal fossil fuel electric power generators. In 2012, the Cape Dorset generator emitted 96.111 and $1.439 \mathrm{t}$ of $\mathrm{NO}_{\mathrm{x}}$ and $\mathrm{PM}_{2.5}$, while the Resolute generator emitted 67.582 and $1.012 \mathrm{t}$ of $\mathrm{NO}_{\mathrm{x}}$ and $\mathrm{PM}_{2.5}$, respectively. Figure 3 shows a map of reported facility emissions for latitudes above $60^{\circ} \mathrm{N}$. $\mathrm{NO}_{\mathrm{x}}$ and $\mathrm{PM}_{2.5}$ sources are scattered in Nunavut, Northwest Territory (NWT), Yukon, and northern Quebec, although there are intensified sources in NWT (diamond mining) and northern Quebec (nickel-copper ore mining). $\mathrm{SO}_{2}$ emissions primarily come from Yukon and NWT (conventional oil and gas extraction).

Table 2 shows the emission summary for Cape Dorset and Resolute in 2011. Only the territorial emission summary was available, so it was assumed that Nunavut has identical emis- 
Table 2. Summaries of air-pollutant emissions for Cape Dorset and Resolute in 2011, listing only categories with emissions of $\mathrm{PM}_{2.5}, \mathrm{SO}_{2}$, and $\mathrm{NO}_{\mathrm{x}}$; scaled using populations of each site and Nunavut (City-Data, 2011; NPRI, 2011).

\begin{tabular}{lcccccc}
\hline Activity & $\begin{array}{c}\text { Cape } \\
\text { Dorset } \\
\mathrm{PM}_{2.5} \\
\text { (tonnes) }\end{array}$ & $\begin{array}{c}\text { Resolute } \\
\mathrm{PM}_{2.5} \\
\text { (tonnes) }\end{array}$ & $\begin{array}{c}\text { Cape } \\
\text { Dorset } \\
\mathrm{SO}_{\mathrm{x}} \\
\text { (tonnes) }\end{array}$ & $\begin{array}{c}\text { Resolute } \\
\mathrm{SO}_{\mathrm{x}} \\
\text { (tonnes) }\end{array}$ & $\begin{array}{c}\text { Cape } \\
\text { Dorset } \\
\mathrm{NO}_{\mathrm{x}} \\
\text { (tonnes) }\end{array}$ & $\begin{array}{c}\text { Resolute } \\
\mathrm{NO}_{\mathrm{x}} \\
\text { (tonnes) }\end{array}$ \\
\hline Cement and concrete industry & 0.256 & 0.040 & - & - & - & - \\
Mining and rock quarrying & 0.043 & 0.007 & - & - & - & - \\
Air transportation & 0.085 & 0.013 & 0.684 & 0.107 & 5.938 & 0.932 \\
Heavy-duty diesel vehicles & 0.043 & 0.007 & - & - & 1.922 & 0.302 \\
Heavy-duty gasoline trucks & - & - & - & - & 0.085 & 0.013 \\
Light-duty diesel trucks & - & - & - & - & 0.085 & 0.013 \\
Light-duty gasoline trucks & - & - & - & - & 2.093 & 0.329 \\
Light-duty gasoline vehicles & - & - & - & - & 0.684 & 0.107 \\
Marine transportation & - & - & 0.043 & 0.007 & 0.256 & 0.040 \\
Off-road use of diesel & 1.922 & 0.302 & 0.043 & 0.007 & 26.529 & 4.165 \\
Off-road use of gasoline/LPG/CNG & 1.111 & 0.174 & - & - & 4.699 & 0.738 \\
Tire wear and brake lining & 0.043 & 0.007 & 0.043 & 0.007 & - & - \\
Cigarette smoking & 0.043 & 0.007 & - & - & - & - \\
Cooking & 0.342 & 0.054 & - & - & - & - \\
Construction operations & 8.715 & 1.368 & - & - & - & - \\
Dust from unpaved roads & 7.390 & 1.16 & - & - & - & - \\
Waste & 0.256 & 0.040 & - & - & 0.085 & 0.013 \\
Mine tailings & 0.513 & 0.080 & - & - & - & - \\
Miscellaneous & 0.384 & 0.060 & - & - & - & - \\
\hline
\end{tabular}

sions per capita in all regions, and the territorial emissions were scaled using populations of Cape Dorset (1363), Resolute (214), and Nunavut (31906), to arrive at a site-specific emission summary (City-Data, 2011). As expected with population scaling, emissions in Cape Dorset are higher than Resolute by a factor of 6.4. Most of the activities contribute to $\mathrm{PM}_{2.5}$ pollution. However, air, marine, off-road diesel, tire wear, and brake lining are the only major contributors to $\mathrm{SO}_{\mathrm{x}}$ pollution. For $\mathrm{NO}_{\mathrm{x}}$ pollution, the transportation sector, offroad use of gasoline/LPG/CNG, and waste burning are major contributors. power plant emissions are significant compared to other sources for each site.

\subsection{Air Quality Health Index (AQHI)}

The air quality index (AQI) is a numeric scale used to quantify air pollution at a given point in time and its health significance. Most AQIs used around the world are calculated by comparing each pollutant in the index to its standard, and reporting the index as the number corresponding to the pollutant that is highest relative to its standard. On the contrary, the Air Quality Health Index used in Canada considers the additive effects of multiple pollutants. AQHI assumes a linear relationship between air pollution and mortality, which is consistent with other no-threshold and dose-response relationships proposed by the World Health Organization (WHO). $\mathrm{AQHI}$ has been developed by examining all possible combinations of two to five common pollutants and various averag- ing times to determine the best and simplest index that statistically correlates with mortality rates. The current version in use considers a trailing $3 \mathrm{~h}$ average of $\mathrm{O}_{3}(\mathrm{ppb}), \mathrm{NO}_{2}$ (ppb), and $\mathrm{PM}_{2.5}\left(\mu \mathrm{g} \mathrm{m}^{-3}\right)$ concentrations (Stieb et al., 2008),

$$
\begin{aligned}
& \mathrm{AQHI}=\frac{1000}{10.4}\left(\exp \left(0.000871\left[\mathrm{NO}_{2}\right]\right)+\right. \\
& \left.\exp \left(0.000537\left[\mathrm{O}_{3}\right]\right)+\exp \left(0.000487\left[\mathrm{PM}_{2.5}\right]\right)-3\right),
\end{aligned}
$$

to produce an index indicative of acute health effects of air pollution. Operationally, AQHI is rounded to the closest integer with an arbitrary minimum value of 1 . AQHI in ranges 1 to 3,4 to 6,7 to 10 , and $>10$ correspond to low risk, moderate risk, high risk, and very high risk, respectively. For the purpose of this study, AQHI is calculated, but not rounded, to provided a measure of air quality at each site with high resolution.

$\mathrm{AQHI}$ is used as a simple tool to put our results in context. Assumptions pertaining to threshold or no-threshold formulations, effect of long-term background pollutants, smoking habits, and other various factors have long been debated in the formulation and output of air quality health models. If a more detailed and accurate health impact assessment of shipping pollution in Arctic communities is desired, a more advanced and statistical health model, such as the Air Quality Benefits Assessment Tool (AQBAT), should be used. Such a model enables the definition of various specific scenario models from the flexibility of combining and linking of 


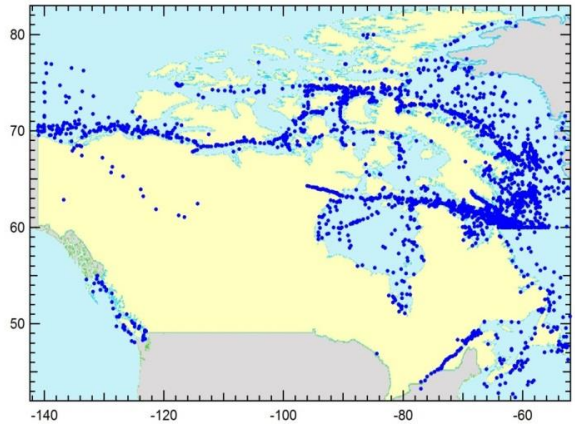

(a) Discrete

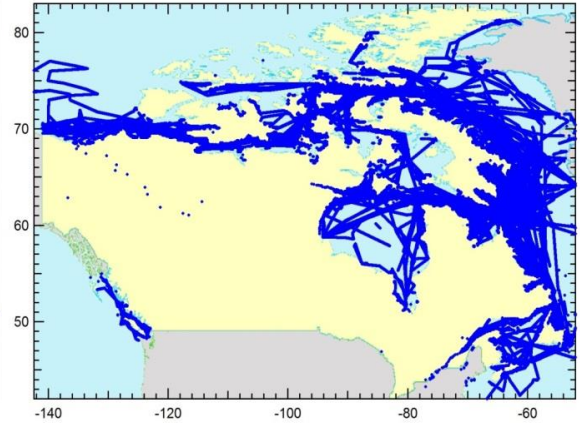

(b) Interpolated

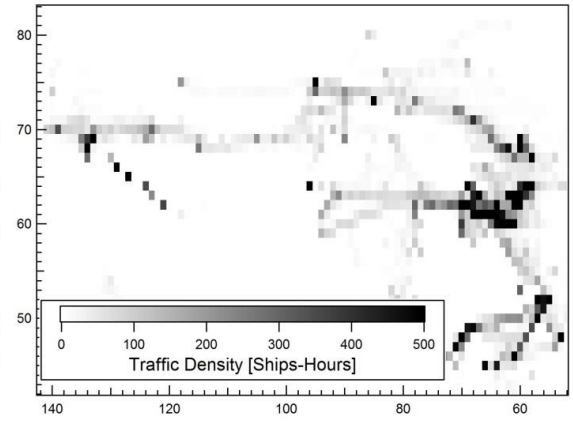

(c) Density

Figure 4. Shipping traffic maps in the Canadian Arctic from 1 June 2013 to 1 November 2013; shipping activity in Mackenzie River (Northwest Territories) not considered; shipping traffic density plot produced with $1^{\circ}$ resolution by integrating number of ships over time in a particular grid box.

pollutants, health endpoints, geographic areas, and scenario years (Judek et al., 2012).

\subsection{Statistical analysis}

Clustering of air masses based on trajectories resulted in a few samples identifying pollutant concentrations or AQHIs associated with each group of trajectories. A statistical estimator was used to construct a confidence interval for the difference in true means between selected sample pairs. Supposing $X_{1}$ is sample 1 and $X_{2}$ is the sample 2 , then the interval for difference between their true means, $\mu_{1}-\mu_{2}$, can be estimated by $\overline{X_{1}}-\overline{X_{2}}$, with $(1-\alpha) \times 100$ confidence, as (Walpole et al., 2002)

$\mu_{1}-\mu_{2} \sim \overline{X_{1}}-\overline{X_{2}} \pm t_{\alpha / 2} \sqrt{\frac{s_{1}^{2}}{n_{1}}+\frac{s_{2}^{2}}{n_{2}}}$,

where $s_{1}$ and $s_{2}$ are sample SDs, $n_{1}$ and $n_{2}$ are sample sizes, and $t_{\alpha / 2}$ is the $t$ value with degrees of freedom $v$ given by

$v=\frac{\left(s_{1}^{2} / n_{1}+s_{2}^{2} / n_{2}\right)^{2}}{\frac{\left(s_{1}^{2} / n_{1}\right)^{2}}{n_{1}-1}+\frac{\left(s_{2}^{2} / n_{2}\right)^{2}}{n_{2}-1}}$.

All intervals for mean differences in this study are constructed with $90 \%$ confidence and are represented as $a-b$ or $a \ldots b$ with $a$ and $b$ showing the lower and upper ends.

\section{Results and discussion}

\subsection{Vessel traffic patterns}

Figure 4 shows the shipping traffic map in the Canadian Arctic from 1 June 2013 to 1 November 2013. The noticeable densities of trips in the Arctic Bridge and the Northwest Passage are evident. To understand ship traffic behavior near each site, the number of ships within a radius of $205 \mathrm{~km}$ from the stations are also counted as a function of date. This distance is the largest width of the ship channels to the south of each station. Traffic near Cape Dorset begins in mid-June and continues toward the end of October, while active traffic near Resolute is limited between late July and early October due to ice conditions and marine navigability. Traffic near Resolute, however, appears denser compared to Cape Dorset. We have observed a maximum of five ships at a time (total of 22) within the vicinity of Resolute, compared to only three ships at a time (total of 39) for Cape Dorset (not shown). This can be explained by the difference between the average widths of Barrow Strait (narrower) and Hudson Strait (wider) as well as limited navigability time near Resolute.

\section{2 air mass trajectories}

The HYSPLIT 5-day trajectory frequency plots are provided in Fig. 5. The frequency plots are computed by counting the number of trajectory intersections over each grid point and dividing by the total number of trajectories. A trajectory may intersect a grid point multiple times, in which case it is theoretically possible to have a frequency greater than $100 \%$ (Draxler et al., 2013). These trajectories cover the Canadian Arctic but extend the origin of air masses beyond the region to include parts of Greenland, northern Asia, and lower latitudes of North America as well. Since the focus of this study is air pollution originating from the Canadian Arctic, we will consider trajectories backward in time for a maximum of 3 days.

\subsection{Air quality measurements and emission sources at the vicinity of each site}

\subsubsection{Pollution as a function of site wind direction}

In a first step toward understanding air pollution, rose plots for pollution concentrations as a function of site wind direction are presented in Fig. 6. The data densities are clearly 


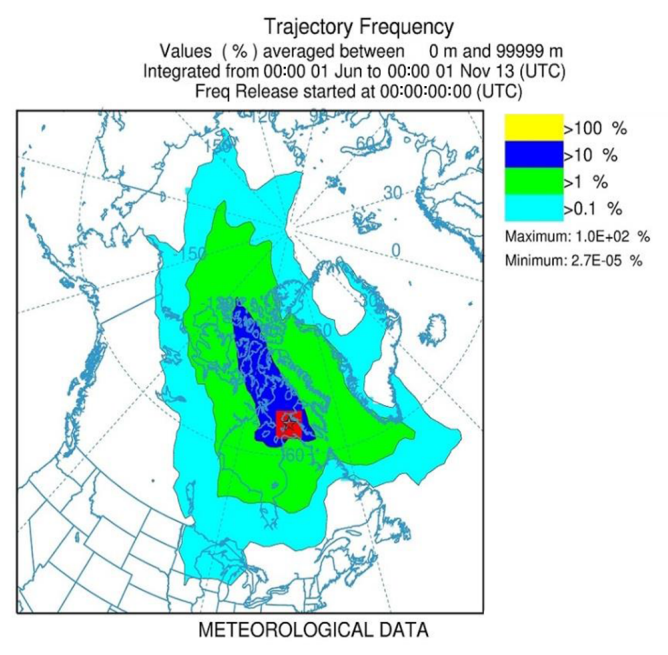

(a) Cape Dorset

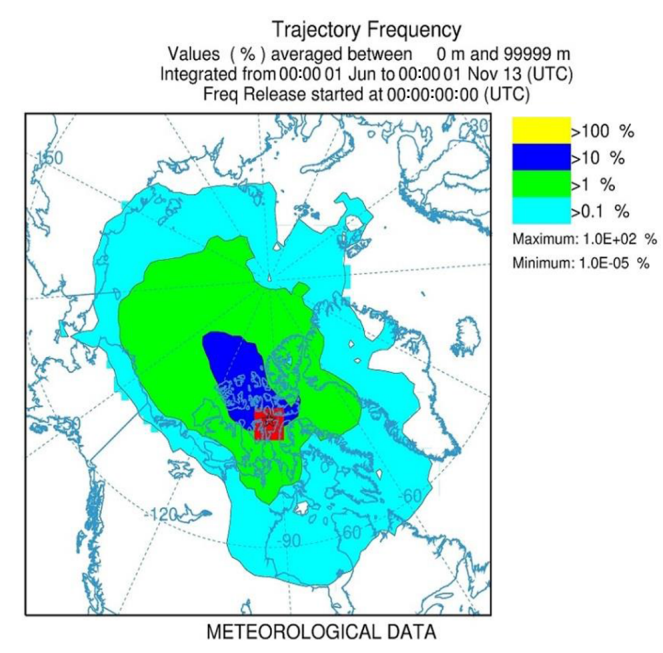

(b) Resolute

Figure 5. HYSPLIT trajectory frequency plots from 1 June 2013 to 1 November 2013.
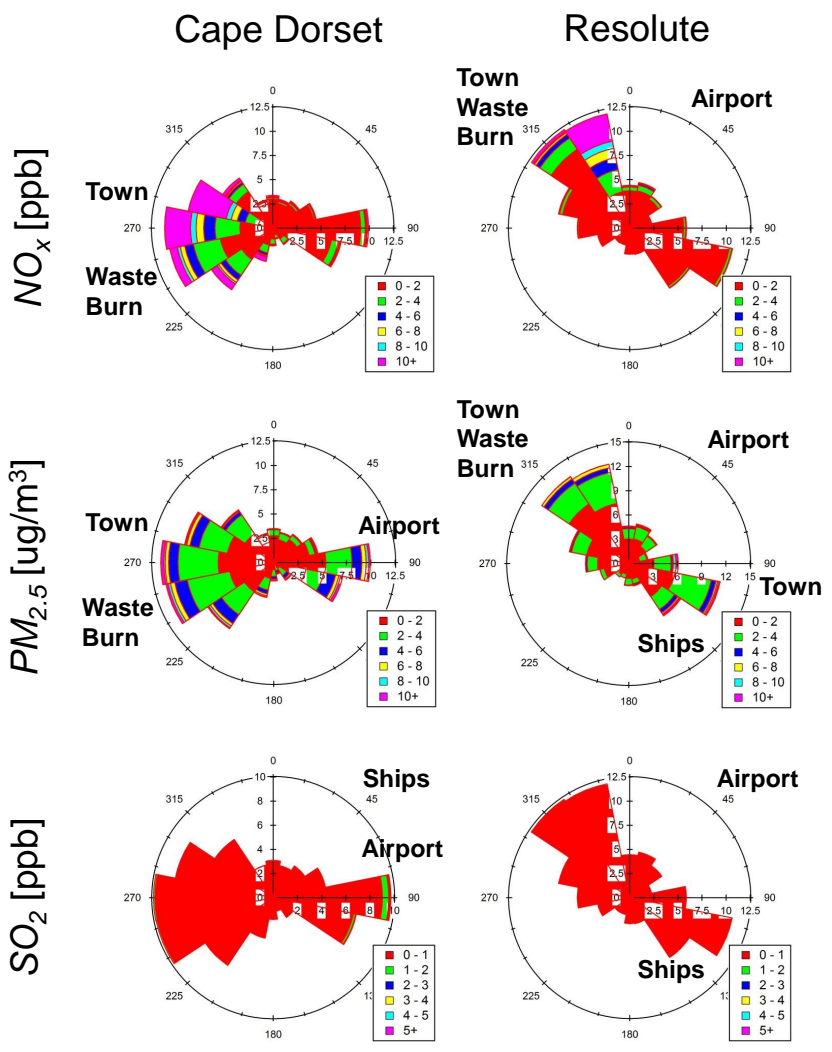

Figure 6. Rose plots for pollution as a function of site wind direction from 1 June 2013 to 1 November 2013; wind roses for $22.5^{\circ}$ sectors with length of each sector indicates frequency $(\%)$ and the color scale indicates concentration. affected by wind patterns provided earlier in Fig. 2. For both Cape Dorset and Resolute, waste burn, the town (vehicle traffic, residential combustion, power generators, etc.), and the airport substantially contribute to $\mathrm{NO}_{\mathrm{x}}$ and $\mathrm{PM}_{2.5}$ pollution, while only airport and ships at anchoring position contribute to $\mathrm{SO}_{2}$ pollution, albeit at low concentrations.

Higher $\mathrm{SO}_{2}$ concentrations from the airport and ships at anchoring position are consistent with the most recent government reports concerning sulfur content in liquid fuels produced in or imported to Canada. In 2009, the national average sulfur concentration in motor gasoline, aviation gasoline, and ultra-low sulfur diesel was $5-17 \mathrm{mg} \mathrm{kg}^{-1}$, while it was 192 $469 \mathrm{mg} \mathrm{kg}^{-1}$ for low-sulfur diesel and aviation turbo fuel (Sulphur, 2012). The latter group of fuels are more widely used by aircrafts and ships, suggesting why $\mathrm{SO}_{2}$ pollution is higher due to air and marine traffic near the sites relative to local traffic.

\subsubsection{Pollution and AQHI time series}

The only noticeable seasonal trend in pollution measurements is the increase in $\mathrm{O}_{3}$ mixing ratio from mid-June to mid-October for both sites (not shown). This is consistent with findings of Helmig et al. (2007) and Shindell et al. (2008) described earlier. Figure 7 shows the 1 min resolution $\mathrm{AQHI}$ time series. The seasonal trend is governed by $\mathrm{O}_{3}$ mixing ratio with $\mathrm{AQHI}$ showing an increase, although very low, from early June to late October. The AQHI in Cape Dorset is higher than Resolute, possibly associated with higher $\mathrm{O}_{3}$ influence from southern sources in North America. 


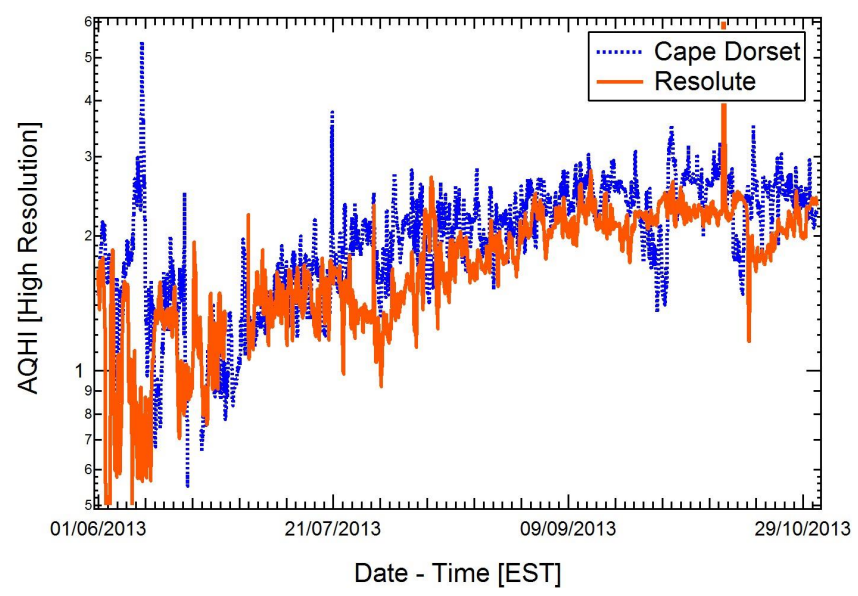

Figure 7. 1 min resolution Air Quality Health Index (AQHI) without rounding.

\subsection{Air quality measurements, air mass trajectories, and shipping traffic}

To identify the effect of shipping traffic on air pollution beyond each site, air mass trajectories and shipping traffic in the Arctic needed to be considered simultaneously. Clustering is the process of grouping air mass trajectories into classes of similar objects. Many algorithms are reported, such as TSV, $k$ means, BIRCH, DBSCAN, OPTICS, and STING, that consider the end point or shape of trajectories in as many subgroups as are statistically significantly different (Lee et al., 2007; Draxler et al., 2013). However, we employed only two simple clustering approaches dubbed static and dynamic.

Static clustering was purely geographical and separated the trajectories based on the place of origin into four sectors: A, B, C, and D, specific to each site. These sectors were identified with the aid of wind direction analysis (Fig. 6) and are shown in Fig. 8. Sectors $\mathrm{A}$ and $\mathrm{C}$ are associated with wind sectors weakly contaminated by local pollution (clear sectors), while it is the opposite for sectors B and D. A sensitivity analysis confirmed that the redefinition of each sector boundary within $\pm 5^{\circ}$ would not affect the results of this analysis significantly.

Dynamic clustering, on the other hand, separated the trajectories in two groups, based on whether or not each trajectory crossed a ship at an elevation less than 100 ma.s.l. and within a lateral distance equal to $20 \%$ of the trajectory length. This threshold is the best estimate for the horizontal error prescribed for trajectories by Stohl (1998). In addition, this approach allows for detection of expanded ship plumes at larger distances from the measurement sites. We used a time resolution of 10 min to track each trajectory backward in time. The success of dynamic clustering of trajectories in detecting ship pollution depends on the accuracies of ship GPS time series as well as the trajectories themselves.
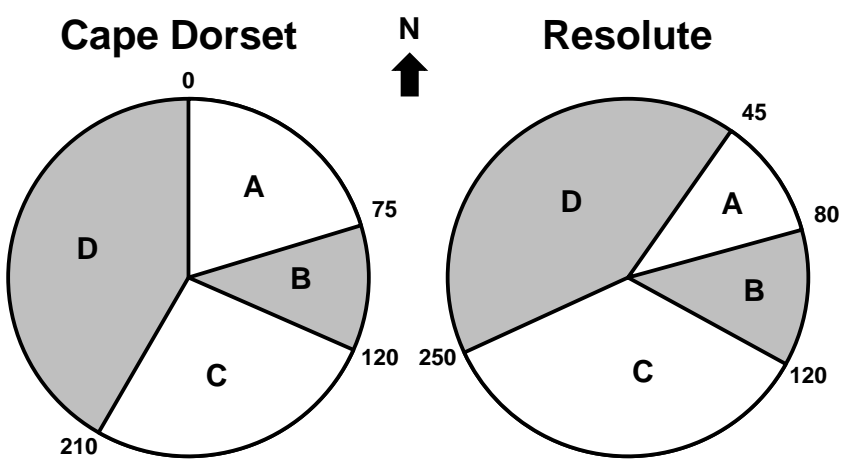

Figure 8. Sectors used for grouping air mass trajectories: trajectories in sectors $\mathrm{A}$ and $\mathrm{C}$ weakly affected by local pollution, while trajectories in sectors B and D strongly affected by local pollution.

\subsubsection{Examples of ship pollution episodes illustrated using selected time series}

Before cluster statistics are discussed, four ship pollution episodes are illustrated using $1 \mathrm{~min}$ resolution time series in Fig. 9. Air masses influenced by ships are indicated by the corresponding plume age near the top of each graph. Ship pollution events are frequently characterized by low/wide peaks in $\mathrm{PM}_{2.5}$ concentrations, $\mathrm{O}_{3}$ mixing ratios, and $\mathrm{AQHI}$, concurrent with ship-influenced air masses. A ship-induced EBC event, concurrent with a $\mathrm{PM}_{2.5}$ and $\mathrm{O}_{3}$ event, has also been characterized in Resolute. $\mathrm{NO}_{\mathrm{x}}$ enhancement by ships occurs less frequently, only for younger plumes. Occasionally, local pollution events are superimposed on top of ship pollution events. These events are characterized by high/narrow peaks $\left(\mathrm{NO}_{\mathrm{x}}, \mathrm{SO}_{2}, \mathrm{PM}_{2.5}\right)$ or valleys $\left(\mathrm{O}_{3}\right.$ titration).

\subsubsection{Static clustering of air mass trajectories based on geographical origin}

As a first step in static clustering of trajectories, the radius distances of trajectories in each cluster to the monitoring stations were computed as a function of trajectory backward time. A backward time selection of $16 \mathrm{~h}$ ensured trajectory coverage over Barrow and Hudson straights. This corresponded to the median of trajectory radii in sector $\mathrm{C}$ exceeding $200 \mathrm{~km}$. The analysis was found to be insensitive to $\pm 8 \mathrm{~h}$ for this backward time selection. The number of trajectories in each sector are reported in Table 3. Figure 10 shows the box and whisker plots for pollution concentration levels. The statistical estimator, defined earlier, is used to build $90 \%$ confidence intervals for mean differences between concentrations for all pairs of air mass samples. The results are shown in Table 4.

The significant effect of local pollution can be observed comparing $\mathrm{NO}_{\mathrm{x}}$ concentrations in sector $\mathrm{D}$ with other sectors in both sites. The $10,25,50,75$, and 90 percentiles are all higher in sector D than the others. The interval for mean 


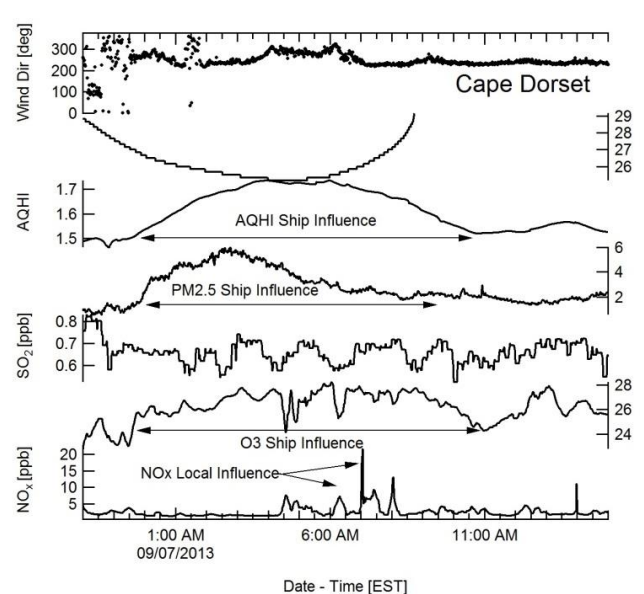

(a) Cape Dorset

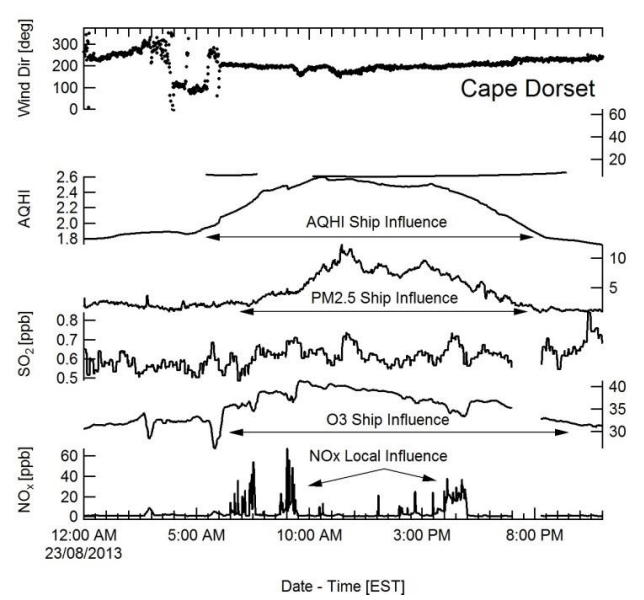

(c) Cape Dorset

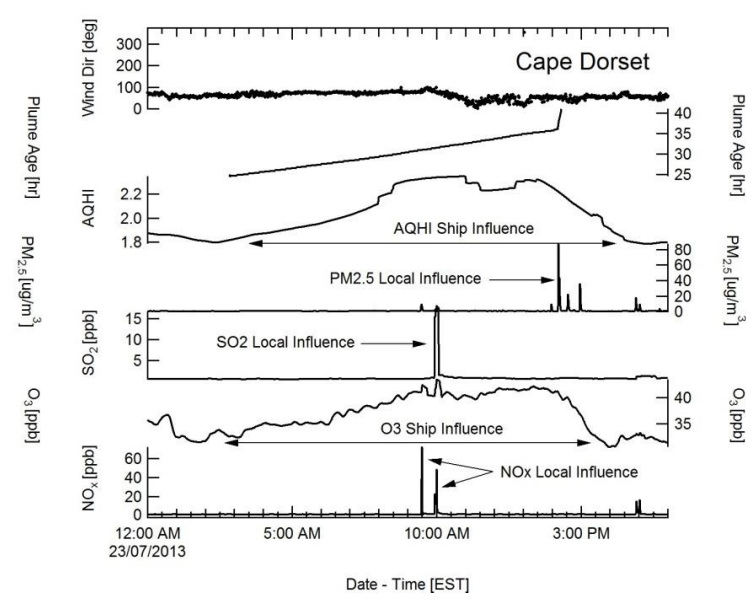

(b) Cape Dorset

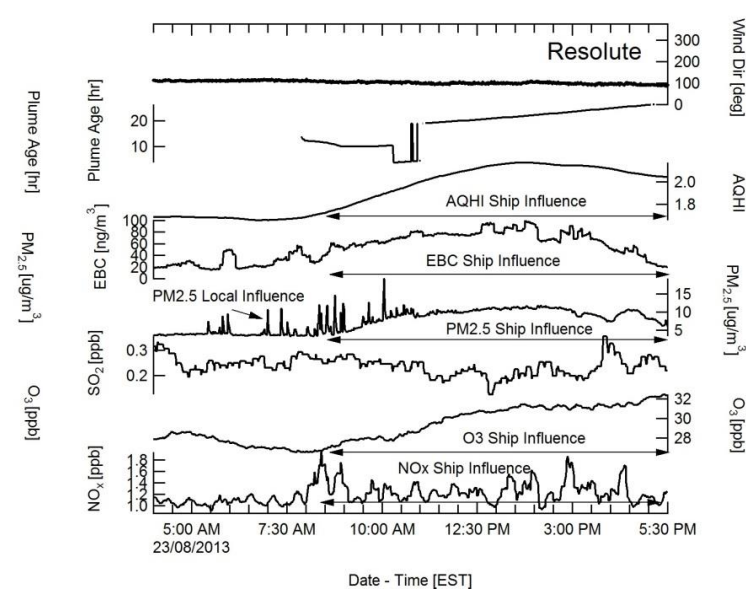

(d) Resolute

Figure 9. Ship pollution episode analysis using time series during selected days; annotated pollution events influenced by ships (wide and low peaks) and local events (narrow and high peaks or valleys).

Table 3. Static cluster sample sizes $n_{k}$ for wind sector $k$ (A, B, C, or D); dynamic cluster sample sizes $n_{j, k}$ for ship influence $j$ (s for ships upstream and ns for no ships upstream) and wind sector $k$ (cws for clear wind sectors, $\mathrm{A}+\mathrm{C}$, and aws for all wind sectors, $\mathrm{A}+\mathrm{B}+\mathrm{C}+\mathrm{D}$ )

\begin{tabular}{|c|c|c|c|c|c|c|c|c|}
\hline Site & $\begin{array}{l}\text { Cape } \\
\text { Dorset }\end{array}$ & $\begin{array}{c}\text { Cape } \\
\text { Dorset }\end{array}$ & $\begin{array}{l}\text { Cape } \\
\text { Dorset }\end{array}$ & $\begin{array}{l}\text { Cape } \\
\text { Dorset }\end{array}$ & Resolute & Resolute & Resolute & Resolute \\
\hline Size & $n_{\mathrm{A}}$ & $n_{\mathrm{B}}$ & $n_{\mathrm{C}}$ & $n_{\mathrm{D}}$ & $n_{\mathrm{A}}$ & $n_{\mathrm{B}}$ & $n_{\mathrm{C}}$ & $n_{\mathrm{D}}$ \\
\hline \multicolumn{9}{|c|}{ Trajectory grouping based on a $16 \mathrm{~h}$ backward time } \\
\hline Static & 31804 & 16883 & 35401 & 123117 & 16494 & 21655 & 38550 & 122929 \\
\hline Size & $n_{\mathrm{s}, \text { aws }}$ & $n_{\mathrm{ns}, \text { aws }}$ & $n_{\mathrm{s}, \mathrm{cws}}$ & $n_{\mathrm{ns}, \mathrm{cws}}$ & $n_{\mathrm{s}, \text { aws }}$ & $n_{\mathrm{ns}, \text { aws }}$ & $n_{\mathrm{S}, \mathrm{cws}}$ & $n_{\mathrm{ns}, \mathrm{cws}}$ \\
\hline \multicolumn{9}{|c|}{ Ship plume age up to $24 \mathrm{~h}$} \\
\hline Dynamic & 32355 & 174446 & 8058 & 40356 & 9984 & 189164 & 4608 & 46271 \\
\hline \multicolumn{9}{|c|}{ Ship plume age up to $72 \mathrm{~h}$} \\
\hline Dynamic & 89582 & 114491 & 21862 & 26548 & 19288 & 177132 & 8115 & 41699 \\
\hline
\end{tabular}



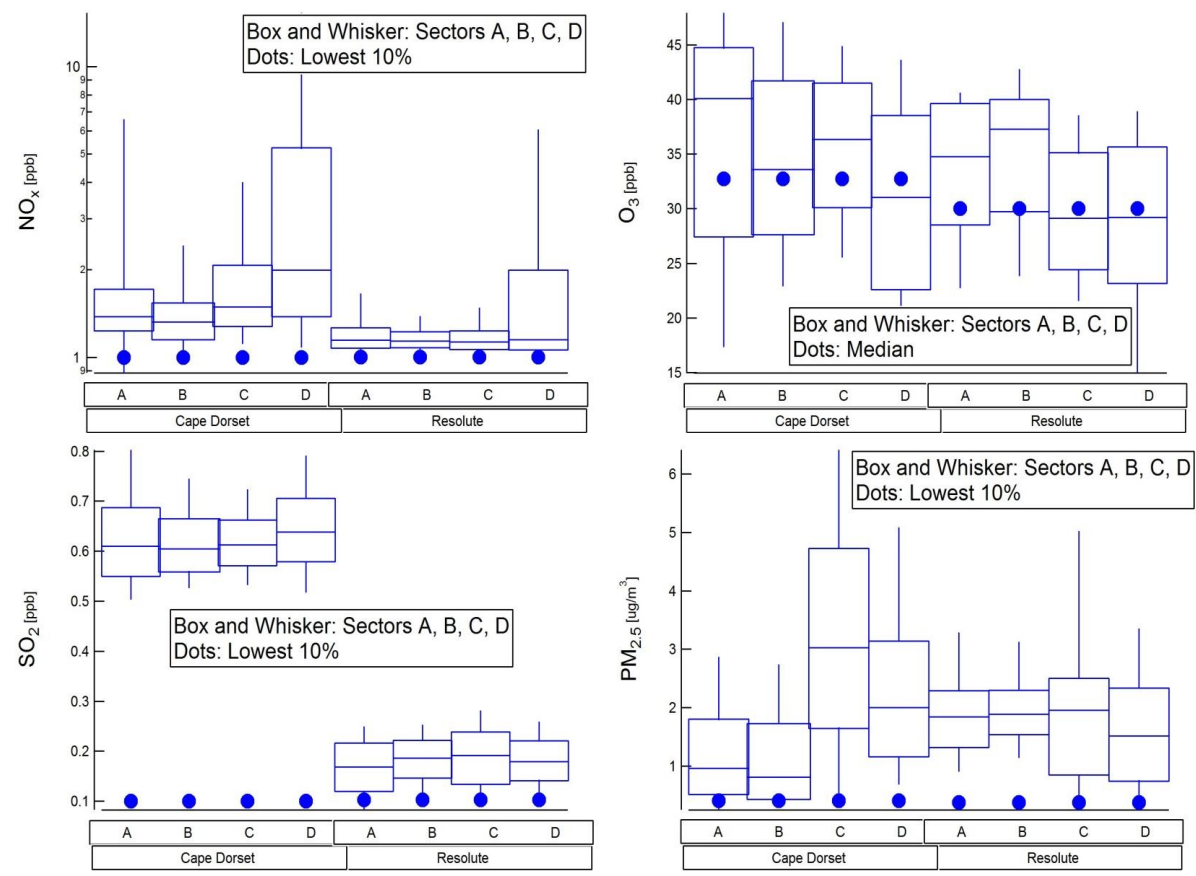

Figure 10. Pollution concentrations based on static clustering of air mass trajectories for Cape Dorset and Resolute; trajectories grouped based on a $16 \mathrm{~h}$ backward time.

difference is up to 3.6-3.8 ppb higher for Cape Dorset and up to $1.6-1.7 \mathrm{ppb}$ higher for Resolute. Highest concentrations in both sites are likely caused by town emissions and waste burn.

Ozone variations are complicated due to a multitude of chemical processes and interactions. The two key chemical processes involved are titration and photochemistry (Sillman, 1999; Seinfeld and Pandis, 2006). Titration results in a drop of $\mathrm{O}_{3}$ mixing ratios due to reaction with $\mathrm{NO}$ that is typical in the vicinity of emission sources rich in NO, often $90 \%$ or more of the total $\mathrm{NO}_{\mathrm{x}}$. Titration time scales are very fast, on the order of $200 \mathrm{~s}$ (Sillman, 1999). Photochemical ozone formation occurs as a result of cyclic reactions that produce ozone (photolysis of $\mathrm{NO}_{2}$ at wavelengths $<424 \mathrm{~nm}$ and ozone generation in the presence of other prerequisite radicals) and those that consume ozone (reaction with NO). This chain of reactions comes to equilibrium to yield a higher ozone mixing ratio than in the absence of sunlight. Using the photostationary state relation as a rough estimate, the steady state ozone mixing ratio should be proportional to $\left[\mathrm{NO}_{2}\right] /[\mathrm{NO}]$ (Sillman, 1999; Seinfeld and Pandis, 2006), a concept that facilitates interpretation of our results. The time scale for photochemical ozone formation is much longer, especially in a cold climate, and is estimated to be greater than $1 \mathrm{~h}$ in our case, preventing ozone formation for long distances downwind of the emission source.

Ozone mixing ratios in sector D for Cape Dorset are down to $5.0-5.1 \mathrm{ppb}$ lower than other sectors, suggesting a reduction in levels due to local titration by town emissions. The mixing ratios from sector $\mathrm{C}$ are comparable to sectors $\mathrm{A}$ and B. For Resolute, sectors $\mathrm{C}$ and $\mathrm{D}$ mixing ratios are down to 6.4-6.5 ppb lower than sectors A and B. This suggests that air masses from the nearby "upper town" (NW) and the airport are ozone titrated while those coming from the distant "lower town" (SE) and ships are ozone enhanced. This argument is supported by examining the ratio $\overline{\left[\mathrm{NO}_{2}\right]} / \overline{[\mathrm{NO}]}$ for both sites. Resolute exhibits a higher ratio 0.95-1.1 compared to Cape Dorset $0.56-0.76$, indicating that the effect of photochemical ozone formation should be stronger in Resolute. In addition, the monitoring station is about $3 \mathrm{~km}$ from the "lower town" in Resolute, as opposed to being in near vicinity of Cape Dorset $(<1 \mathrm{~km})$, leaving enough time for air masses to age and photochemistry to be triggered.

There is no statistically significant difference among $\mathrm{SO}_{2}$ levels associated with sectors $\mathrm{A}, \mathrm{B}, \mathrm{C}$, and $\mathrm{D}$. $\mathrm{SO}_{2}$ pollution events are very rare and episodic, so that they do not reflect any change in the box and whisker plots either.

$\mathrm{PM}_{2.5}$ concentration in air masses arriving at Cape Dorset from sector $\mathrm{C}$ is up to $1.4-1.5 \mu \mathrm{g} \mathrm{m}^{-3}$ higher than other sectors and so are the 25, 50,75, and 90 percentiles. This may be attributed to shipping activity and other sources from the south (e.g., nickel mining in Northern Quebec). In Resolute, concentrations in sector $\mathrm{D}$ are down to $1.0-1.2 \mu \mathrm{g} \mathrm{m}{ }^{-3}$ lower than other sectors. This sector faces the frozen ocean with minimal shipping activity for extended periods. 

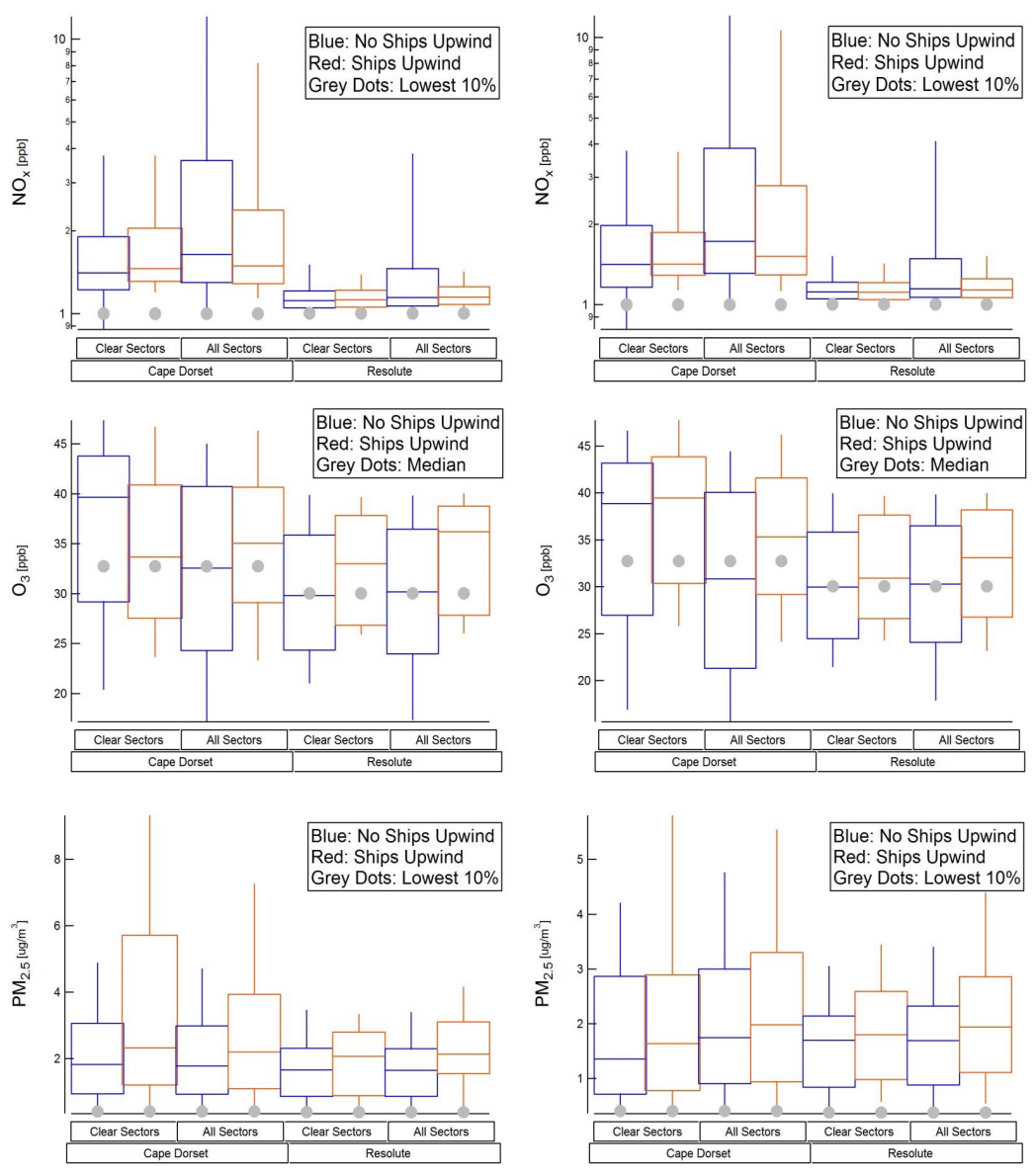

(a) Ship plume age up to $24 \mathrm{hr}$

(b) Ship plume age up to $72 \mathrm{hr}$

Figure 11. Pollution concentrations based on dynamic clustering of air mass trajectories.

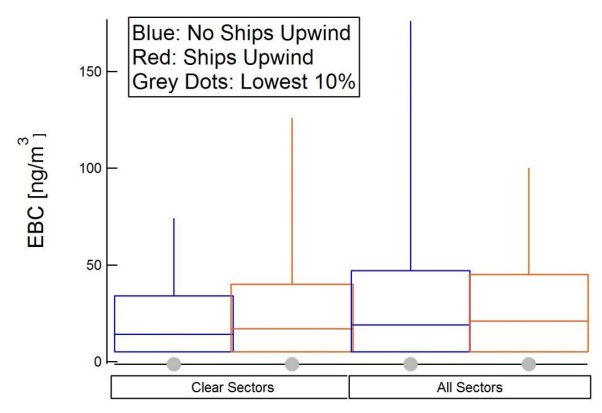

(a) Ship plume age up to $24 \mathrm{hr}$

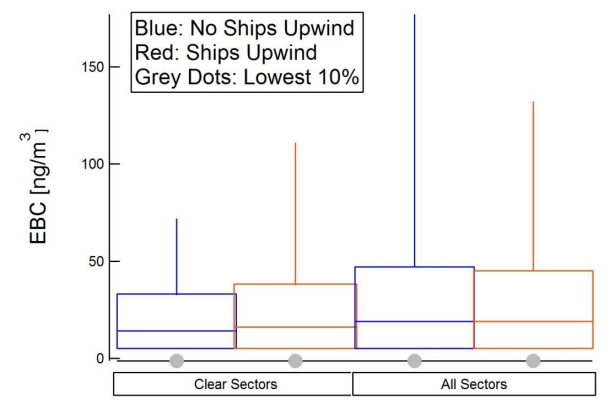

(b) Ship plume age up to $72 \mathrm{hr}$

Figure 12. Equivalent black carbon (EBC) based on dynamic clustering of air mass trajectories in Resolute.

\subsubsection{Dynamic clustering of air mass trajectories based on ship presence upstream}

Dynamic clustering of air mass trajectories was performed based on grouping air masses into clear $(\mathrm{A}+\mathrm{C})$ and all $(\mathrm{A}+\mathrm{B}+\mathrm{C}+\mathrm{D})$ wind sectors and then sub-grouping based on ship influence ( $\mathrm{s}$ for ship-influenced and ns for no ship-influenced). Ship plume ages up to $24 \mathrm{~h}$ and $72 \mathrm{~h}$ were considered and the number of trajectories in each group/subgroup are reported in Table 3. Figures 11-13 show the box and whisker plots for pollution concentration levels and AQHI. The statistical estimator for mean differences are shown in Tables 5 and 6. 


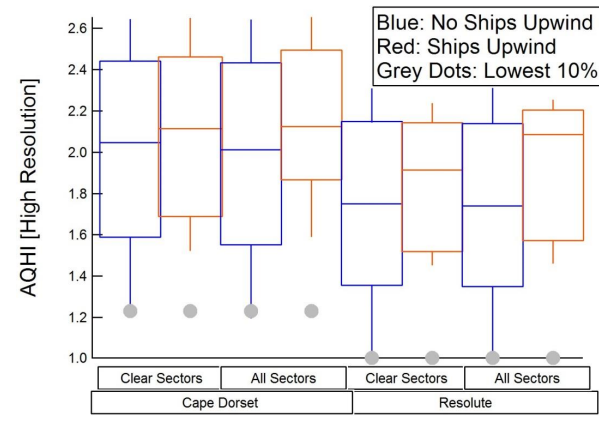

(a) Ship plume age up to $24 \mathrm{hr}$

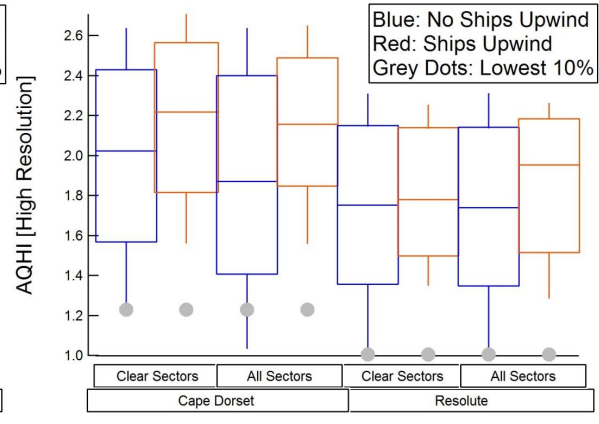

(b) Ship plume age up to $72 \mathrm{hr}$

Figure 13. AQHI based on dynamic clustering of air mass trajectories.

Table 4. Estimator for differences in true means between concentrations (ppb for gases and $\mu \mathrm{g} \mathrm{m}^{-3}$ for $\mathrm{PM}_{2.5}$ ) associated with static air mass clusters in Cape Dorset and Resolute; trajectories grouped based on a $16 \mathrm{~h}$ backward time; $\overline{C_{\text {row }}-C_{\text {col }}}$ (e.g., $\overline{C_{\mathrm{B}}-C_{\mathrm{A}}}$ for entry in row $\mathrm{B}$ and column A) estimator for concentration difference; lower and upper limits with $90 \%$ confidence interval; intervals above instrument precision in bold face.

\begin{tabular}{|c|c|c|c|c|c|c|}
\hline Site & $\begin{array}{l}\text { Cape } \\
\text { Dorset }\end{array}$ & $\begin{array}{l}\text { Cape } \\
\text { Dorset }\end{array}$ & $\begin{array}{l}\text { Cape } \\
\text { Dorset }\end{array}$ & Resolute & Resolute & Resolute \\
\hline $\mathrm{NO}_{\mathrm{x}}$ & A & B & $\mathrm{C}$ & A & B & $\mathrm{C}$ \\
\hline B & $-1.5 \ldots-1.3$ & & & $-0.2 \ldots-0.2$ & & \\
\hline $\mathrm{C}$ & $-0.1 \ldots 0.0$ & $1.3 \ldots 1.4$ & & $0.0 \ldots 0.0$ & $0.0 \ldots 0.0$ & \\
\hline $\mathrm{D}$ & $2.3 \ldots 2.4$ & $3.6 \ldots 3.8$ & $2.3 \ldots 2.4$ & $0.1 \ldots .0 .2$ & $1.6 \ldots 1.7$ & $1.5 \ldots 1.5$ \\
\hline $\mathrm{O}_{3}$ & A & B & $\mathrm{C}$ & A & B & $\mathrm{C}$ \\
\hline B & $-1.2 \ldots-1.0$ & & & $1.3 \ldots 1.5$ & & \\
\hline $\mathrm{C}$ & $-0.3 \ldots-0.1$ & 0.9...1.1 & & $-3.9 \ldots-3.8$ & $-5.3 \ldots-5.2$ & \\
\hline $\mathrm{D}$ & $-5.1 \ldots-5.0$ & $-4.0 \ldots-3.8$ & $-4.9 \ldots-4.8$ & $-5.1 \ldots-4.9$ & $-6.5 \ldots-6.4$ & $-1.2 \ldots-1.1$ \\
\hline $\mathrm{PM}_{2.5}$ & A & B & $\mathrm{C}$ & A & B & $\mathrm{C}$ \\
\hline $\mathrm{B}$ & $0.0 \ldots 0.0$ & & & $-0.7 \ldots-0.5$ & & \\
\hline $\mathrm{C}$ & $2.1 \ldots 2.2$ & $2.2 \ldots 2.2$ & & $-0.6 \ldots-0.4$ & $0.1 \ldots 0.1$ & \\
\hline $\mathrm{D}$ & $1.4 \ldots 1.4$ & $1.4 \ldots 1.5$ & $-0.8 \ldots-0.7$ & $-1.2 \ldots-1.0$ & $-0.5 \ldots-0.4$ & $-0.6 \ldots-0.5$ \\
\hline
\end{tabular}

For $\mathrm{NO}_{\mathrm{x}}$, the comparison of clear and all wind sectors again reveals that the effect of local pollution is significant. Considering the clear wind sectors only, there is no statistically significant difference in $\mathrm{NO}_{\mathrm{x}}$ concentrations as a result of ship influence. However, considering all wind sectors, $\mathrm{NO}_{\mathrm{x}}$ concentrations by local pollution are higher than concentrations in ship-influenced air masses by $0.7-0.9 \mathrm{ppb}$ in Cape Dorset and 1.0-1.1 ppb in Resolute. Box and whisker plots also show a substantial increase in 75 and 90 percentiles. Air masses contaminated by high sporadic local pollution are not necessarily coincident with ship-influenced air masses, so our approach to grouping identifies them under "no ship-influenced" condition, explaining why no shipinfluenced air masses exhibit higher concentrations.

For $\mathrm{O}_{3}$, the comparison of clear and all wind sectors in Cape Dorset reveals that local emissions reduce ozone levels due to immediate titration. We have frequently observed a pronounced anticorrelation between local $\mathrm{NO}_{\mathrm{x}}$ and $\mathrm{O}_{3}$ levels (see Fig. 9). Median ozone levels for ship-influenced air masses are greater than the overall median ozone for both clear and all wind sectors in both sites. Under clear wind sectors in Cape Dorset, air masses contaminated by ship plumes up to $24 \mathrm{~h}$ of age show a decrease in mixing ratios by $1.6-2.0 \mathrm{ppb}$ but an increase by $2.1-2.4 \mathrm{ppb}$ for plumes up to $72 \mathrm{~h}$ old. Under all wind sectors in Cape Dorset, shipping enhances mixing ratios by $2.7-2.9 \mathrm{ppb}$ and $4.6-4.7 \mathrm{ppb}$ for plumes up to $24 \mathrm{~h}$ and $72 \mathrm{~h}$ of age, respectively. In Resolute, we see an increase of mixing ratios due to shipping by $2.7-$ $3.1 \mathrm{ppb}$ and 4.3-4.5 ppb under clear and all wind sectors for plumes up to $24 \mathrm{~h}$ of age and by $1.6-1.8 \mathrm{ppb}$ and $2.5-2.7 \mathrm{ppb}$ under the same sectors for plumes up to $72 \mathrm{~h}$ of age. For both sites, ozone pollution appears to be long lived and persistent in ship plumes for at least $72 \mathrm{~h}$. Our results suggest that photochemical ozone enhancement in ship plumes crossing Resolute is triggered more effectively than Cape Dorset, in agreement with the hypothesis of photostationary state relation mentioned earlier. 
Table 5. Estimator for differences in true means between concentrations ( $\mathrm{ppb}$ for gases, $\mu \mathrm{g} \mathrm{m}{ }^{-3}$ for $\mathrm{PM}_{2.5}$ and $\mathrm{ng} \mathrm{m}^{-3}$ for EBC) associated with dynamic air mass clusters in Cape Dorset and Resolute; $\overline{C_{\mathrm{s} \text {, aws }}-C_{\mathrm{ns}} \text {, aws }}$ and $\overline{C_{\mathrm{s}, \text { cws }}-C_{\mathrm{ns}, \mathrm{cws}}}$ estimator for concentration difference; subscripts definitions as in caption of Table 3; lower and upper limits with $90 \%$ confidence interval; intervals above instrument precision in bold face.

\begin{tabular}{|c|c|c|c|c|}
\hline Site & Cape Dorset & Cape Dorset & Resolute & Resolute \\
\hline estimator & $\overline{C_{\mathrm{s}, \mathrm{aws}}-C_{\mathrm{ns}, \mathrm{aws}}}$ & $\overline{C_{\mathrm{s}, \mathrm{cws}}-C_{\mathrm{ns}, \mathrm{cws}}}$ & $\overline{C_{\mathrm{s}, \text { aws }}-C_{\mathrm{ns}, \text { aws }}}$ & $\overline{C_{\mathrm{s}, \mathrm{cws}}-C_{\mathrm{ns}, \mathrm{cws}}}$ \\
\hline \multicolumn{5}{|c|}{ Ship plume age up to $24 \mathrm{~h}$} \\
\hline $\mathrm{NO}_{\mathrm{x}}$ & $-0.9 \ldots-0.7$ & $0.0 \ldots 0.3$ & $-1.1 \ldots-1.0$ & $-0.1 \ldots 0.0$ \\
\hline $\mathrm{O}_{3}$ & $2.7 \ldots 2.9$ & $-2.0 \ldots-1.6$ & $4.3 \ldots 4.5$ & $2.7 \ldots 3.1$ \\
\hline $\mathrm{PM}_{2.5}$ & $0.6 \ldots 0.6$ & $1.8 \ldots 1.9$ & $0.5 \ldots 0.6$ & $0.0 \ldots 0.1$ \\
\hline $\mathrm{EBC}$ & & & $-29.8 \ldots 6.7$ & $0.4 \ldots 10.1$ \\
\hline \multicolumn{5}{|c|}{ Ship plume age up to $72 \mathrm{~h}$} \\
\hline $\mathrm{NO}_{\mathrm{x}}$ & $0.0 \ldots 0.1$ & $0.2 \ldots 0.4$ & $-1.1 \ldots-1.1$ & $-0.1 \ldots 0.0$ \\
\hline $\mathrm{O}_{3}$ & $4.6 \ldots 4.7$ & $2.1 \ldots 2.4$ & $2.5 \ldots 2.7$ & $1.6 \ldots 1.8$ \\
\hline $\mathrm{PM}_{2.5}$ & $0.0 \ldots 0.1$ & $0.4 \ldots 0.5$ & $0.4 \ldots 0.5$ & $0.1 \ldots 0.2$ \\
\hline $\mathrm{EBC}$ & & & $-26.9 \ldots-7.8$ & $-0.3 \ldots 4.5$ \\
\hline
\end{tabular}

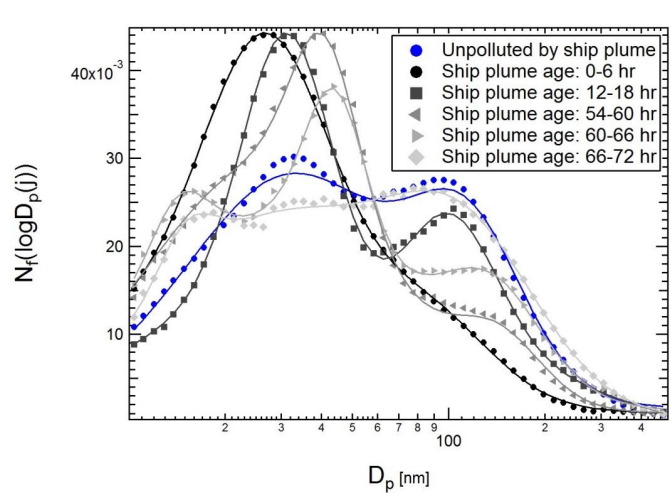

(a) As a function of ship plume age

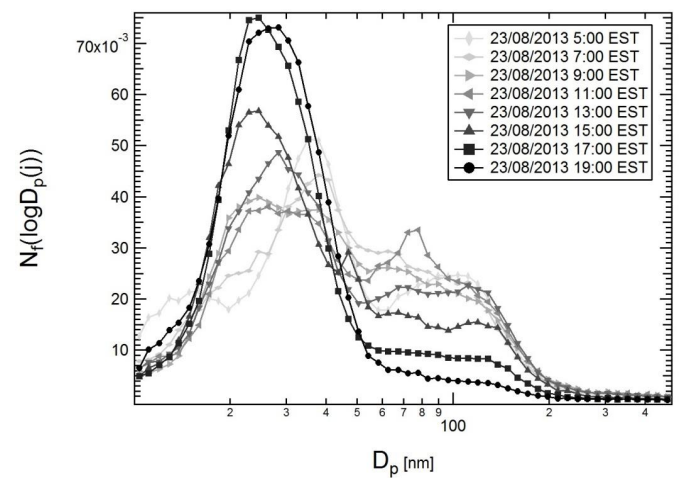

(b) For a single ship pollution event as in Fig. 9

Figure 14. Particle size number fraction in Resolute.

The influence of shipping emissions on $\mathrm{PM}_{2.5}$ concentrations is significant under clear and all wind sectors for both sites for plumes up to $24 \mathrm{~h}$ of age. The 25, 50, 75, and 90 percentiles for $\mathrm{PM}_{2.5}$ levels are consistently greater for shipinfluenced air masses than the rest. Statistical mean differences are higher for Cape Dorset by $1.8-1.9 \mu \mathrm{g} \mathrm{m}^{-3}$ under clear wind sectors and for Resolute by $0.5-0.6 \mu \mathrm{g} \mathrm{m}^{-3}$ under all wind sectors. Unlike ozone, however, the $\mathrm{PM}_{2.5}$ influence is not persistent from older ship plumes (up to $72 \mathrm{~h}$ ) so that the statistical mean differences drop and the degree of overlap in box and whisker plots increases.

In Resolute, the influence of shipping emissions on EBC concentrations is significant only under clear wind sectors for plumes up to $24 \mathrm{~h}$ of age. The 50,75 , and 90 percentiles for EBC levels are greater for ship-influenced air masses, and the statistical mean difference is higher by $0.4-10.1 \mathrm{ng} \mathrm{m}^{-3}$. Under all wind sectors, the sporadic nature of local pollution results in higher EBC concentrations. Similar to $\mathrm{PM}_{2.5}$, the influence of EBC from older ship plumes (up to $72 \mathrm{~h}$ ) is less persistent, likely due to particle deposition.

There is a persistent increase in AQHI for ship-influenced air masses in both sites for plumes up to 24 and $72 \mathrm{~h}$ of age. The mean difference in AQHI between ship and no shipinfluenced air masses varies from 0.1 to 0.3 , in a statistically significant way, with current traffic levels.

\subsubsection{Particle size distributions}

The fate of particles in ship plumes was studied, to a limited extent and by speculation, using particle size number fractions in Resolute. Figure 14 shows particle size number fraction as a function of ship plume age for the entire data set. Also, the particle size number fraction change for a single ship pollution episode (same as in Fig. 9) is shown. For ship plume aging analysis, the dynamic cluster containing shipinfluenced air masses was further sub-grouped by plume age from 0 to $72 \mathrm{~h}$ in $6 \mathrm{~h}$ time intervals. The distributions corresponding to ship-polluted air masses are averaged over large 
Table 6. Estimator for differences in true means between AQHI associated with dynamic air mass clusters in Cape Dorset and Resolute; $\overline{I_{\mathrm{S}} \text {, aws }}-I_{\mathrm{ns}, \text { aws }}$ and $\overline{I_{\mathrm{S}, \mathrm{cws}}-I_{\mathrm{ns}, \mathrm{cws}}}$ estimator for index difference; subscripts definitions as in caption of Table 3; lower and upper limits with $90 \%$ confidence interval.

\begin{tabular}{|c|c|c|c|c|}
\hline $\begin{array}{l}\text { Site } \\
\text { estimator }\end{array}$ & Cape Dorset & Cape Dorset & Resolute & Resolute \\
\hline \multicolumn{5}{|c|}{ Ship plume age up to $24 \mathrm{~h}$} \\
\hline AQHI & $0.2 \ldots 0.2$ & $0.1 \ldots 0.1$ & $0.2 \ldots 0.2$ & $0.1 \ldots 0.1$ \\
\hline \multicolumn{5}{|c|}{ Ship plume age up to $72 \mathrm{~h}$} \\
\hline AQHI & $0.2 \ldots 0.3$ & $0.2 \ldots 0.2$ & $0.1 \ldots 0.1$ & $0.1 \ldots 0.1$ \\
\hline
\end{tabular}
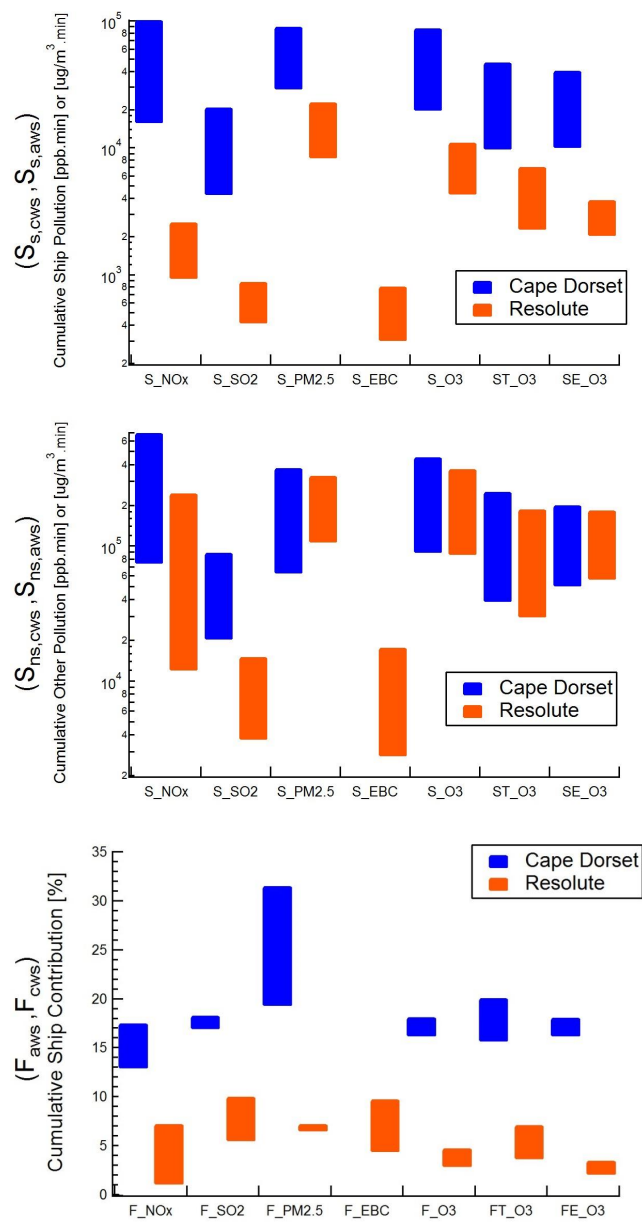

Figure 15. Contribution of shipping and other sources to cumulative pollution; lower and upper bounds based on clear and all wind sectors.

sample clusters or time periods to reduce the effect of local pollution on size distribution, which cannot be totally eliminated with the current methodology. Local pollution is predominantly short-lived with narrow peaks in pollution time series in comparison to the long-lived ship pollution with wide peaks in the time series (see Fig. 9). With this strategy the study of size distribution dynamics as a function of ship plume age becomes easier. Using genetic optimization, a four-modal log-normal function was fitted to each subgroup sample:

$$
\begin{aligned}
& N_{\mathrm{f}}\left(\log D_{\mathrm{p}}(j)\right) \simeq \frac{\mathrm{d} N_{\mathrm{f}}\left(\log D_{\mathrm{p}}(j)\right)}{\mathrm{d} \log D_{\mathrm{p}}} \Delta \log D_{\mathrm{p}} \\
& \simeq \sum_{i=1}^{4} \frac{N_{\mathrm{f}, i} \Delta \log D_{\mathrm{p}}}{\sqrt{2 \pi} \log \sigma_{i}} \exp \left(-\frac{1}{2}\left[\frac{\log D_{\mathrm{p}}(j)-\log D_{\mathrm{m}, i}}{\log \sigma_{i}}\right]^{2}\right),
\end{aligned}
$$

where $N_{\mathrm{f}}\left(\log D_{\mathrm{p}}(j)\right)$ is particle number fraction for particle diameters in the $j$ th bin of the instrument $\left(\log D_{\mathrm{p}}(j)\right)$ in nm, and $\Delta \log D_{\mathrm{p}}$ is the average bin width in $\mathrm{nm}$ for all channels. The other parameters are mode dependent: $N_{\mathrm{f}, i}$ is total particle number fraction, $D_{\mathrm{m}, i}$ is particle median diameter, and $\sigma_{i}$ is a measure of spread for mode $i$. The combination $\frac{N_{\mathrm{f}, i} \Delta \log D_{\mathrm{p}}}{\sqrt{2 \pi} \log \sigma_{i}}$ may be interpreted as the amplitude for mode $i$.

Figure 14 and Table 7 show selected particle size number fractions and the associated parameters for the four-modal log-normal fits. These results do not resolve variability in engine type, engine load, and fuel type due to the limited scope of the analysis and the limited number of samples available for each ship plume encountered. However, information on individual engine types, sizes, and fuels are available from classification societies such as IHS Fairplay, DNV GL Exchange, American Bureau of Shipping, Korean Register, Russian ship register, Class NK, and Bureau Veritas. Nevertheless, a number of interesting anthropogenic and biogenic processes can be identified using the particle size number fractions.

The unpolluted number fraction (background), with long residence time over marine boundary layer and nearby islands, exhibits two strong modes in Aitken (28-37 nm) and accumulation $(105-115 \mathrm{~nm})$ regimes, in agreement with findings of Petzold et al. (2008). The fresh plumes (0-6h) exhibit a weak nucleation mode at $13 \mathrm{~nm}$, an accentuated combustion (Aitken) mode at $27 \mathrm{~nm}$, and a weaker combustion mode at $85 \mathrm{~nm}$. These findings are in agreement with the plume intercept and test-rig studies of Petzold et al. (2008, 2010, 2011), who report nucleation and combustion modes in ranges of $5-15 \mathrm{~nm}$ and $25-90 \mathrm{~nm}$, respectively. It is speculated that lower and higher combustion modes are associ- 
Table 7. Parameters for the four-modal log-normal fits to the particle size number fractions as a function of ship plume age in Resolute; nucleation (Nuc), Aitken (Ait), and accumulation (Acc) modes annotated in the table.

\begin{tabular}{lllllll}
\hline Ship plume age (h) & Unpolluted & $0-6$ & $12-18$ & $54-60$ & $60-66$ & $66-72$ \\
\hline \# of samples & - & 323 & 87 & 218 & 214 & 62 \\
\hline$\frac{N_{\mathrm{f}, 1} \Delta \log D_{\mathrm{p}}}{\sqrt{2 \pi} \log \sigma_{1}}$ & 0.018 & 0.002 & 0.013 & 0.003 & 0.007 & 0.006 \\
$D_{\mathrm{m}, 1}(\mathrm{~nm})$ & $28^{\text {Ait }}$ & 3 & $25^{\text {Ait }}$ & $23^{\text {Ait }}$ & $14^{\mathrm{Nuc}}$ & $15^{\mathrm{Nuc}}$ \\
$\sigma_{1}(\mathrm{~nm})$ & 2 & 7 & 3 & 3 & 1 & 1 \\
\hline$\frac{N_{\mathrm{f}, 2} \Delta \log D_{\mathrm{p}}}{\sqrt{2 \pi} \log \sigma_{2}}$ & 0.009 & 0.009 & 0.031 & 0.026 & 0.022 & 0.020 \\
$D_{\mathrm{m}, 2}(\mathrm{~nm})$ & $37^{\mathrm{Ait}}$ & $13^{\mathrm{Nuc}}$ & $31^{\mathrm{Ait}}$ & $27^{\text {Ait }}$ & $28^{\mathrm{Ait}}$ & $28^{\mathrm{Ait}}$ \\
$\sigma_{2}(\mathrm{~nm})$ & 2 & 3 & 1 & 2 & 3 & 2 \\
\hline$\frac{N_{\mathrm{f}, 3} \Delta \log D_{\mathrm{p}}}{\sqrt{2 \pi} \log \sigma_{3}}$ & 0.004 & 0.034 & 0.018 & 0.018 & 0.017 & 0.003 \\
$D_{\mathrm{m}, 3}(\mathrm{~nm})$ & $105^{\mathrm{Acc}}$ & $27^{\mathrm{Ait}}$ & $101^{\mathrm{Acc}}$ & $41^{\mathrm{Ait}}$ & $44^{\mathrm{Ait}}$ & $56^{\mathrm{Ait}}$ \\
$\sigma_{3}(\mathrm{~nm})$ & 2 & 1 & 1 & 1 & 1 & 3 \\
\hline$\frac{N_{\mathrm{f}, 4} \Delta \log D_{\mathrm{p}}}{\sqrt{2 \pi} \log \sigma_{4}}$ & 0.015 & 0.009 & 0.004 & 0.007 & 0.009 & 0.016 \\
$D_{\mathrm{m}, 4}(\mathrm{~nm})$ & $115^{\mathrm{Acc}}$ & $85^{\mathrm{Ait}}$ & $208^{\mathrm{Acc}}$ & $144^{\mathrm{Acc}}$ & $138^{\mathrm{Acc}}$ & $112^{\mathrm{Acc}}$ \\
$\sigma_{4}(\mathrm{~nm})$ & 1 & 2 & 2 & 1 & 1 & 2 \\
\hline
\end{tabular}

ated with primary and agglomerated black carbon particles (Petzold et al., 2011). A plume intercept study by Lack et al. (2011) found that the median particle size associated with the strongest combustion mode decreased concurrent with the decrease of sulfate $\left(\mathrm{SO}_{4}^{2-}\right)$ emissions from $60 \mathrm{~nm}$ to $36 \mathrm{~nm}$. Another plume intercept study by Cappa et al. (2014) shows the same mode shifting concurrent with lower engine speeds (loads) from $69 \mathrm{~nm}$ at 12 knots to $30 \mathrm{~nm}$ at 2.9 knots. Thus, it is likely that the detected combustion modes in our analysis are affected by variability in both vessel speeds and sulfur content in their fuels.

The particle size number fraction exhibits complex dynamics as the plumes age beyond $6 \mathrm{~h}$. The major combustion mode particle size increases due to particle coagulation and growth from $27 \mathrm{~nm}(0-6 \mathrm{~h})$ to $44 \mathrm{~nm}(60-66 \mathrm{~h})$, but eventually attenuates in number fraction. Meanwhile, the accumulation mode appears at $101 \mathrm{~nm}(12-18 \mathrm{~h})$ and intensifies until it approaches the background mode at $112 \mathrm{~nm}$ (66$72 \mathrm{~h}$ ). For ocean-originated air masses, a nucleation mode appears at $14 \mathrm{~nm}(60-66 \mathrm{~h})$ and persists at $15 \mathrm{~nm}(66-72 \mathrm{~h})$. We suggest that this mode is linked to biogenic sulfur emissions from the ocean in the summer Arctic. Dimethyl sulfide (DMS) emissions play an important role in influencing aerosols in the Arctic ocean (Sharma et al., 1999) and have long atmospheric lifetimes (8 days) compared to lower latitudes (0.8 days) (Sharma et al., 2012). DMS is produced in the ocean, with the highest concentrations measured especially near the ice edge (Sharma et al., 2012), and exchanged to the atmosphere, where it reacts/oxidizes with other radicals to produce compounds that further condense on existing particles or nucleate into new particles (Yin and Seinfeld, 1990; Capaldo and Pandis, 1997). The accumulation mode may also be influenced by ocean-originated sea salt, as suggested by O'Dowd et al. (1997).

Our plume aging analysis suggests that particle processing in the Arctic is very slow, requiring up to $72 \mathrm{~h}$ until background conditions in particle size number fractions are reached. The hourly particle size number fraction change in the single ship plume episode demonstrates the transformation of the background distribution to a distribution dominated by combustion mode particles in the 20 to $30 \mathrm{~nm}$ diameter range in the ship plume, giving confidence in our hypotheses about the particle size distribution behavior for the entire data set.

\subsubsection{Contribution of shipping and other sources to cumulative pollution}

To estimate the contribution of shipping to cumulative pollution, a measure of local exposure, the surface level concentrations are integrated over time. It can be argued that the clear wind sectors $(\mathrm{A}+\mathrm{C})$ provide a lower bound estimate for cumulative ship pollution since those air masses are weakly affected by local pollution, while all wind sectors $(\mathrm{A}+\mathrm{B}+\mathrm{C}+\mathrm{D})$ provide an upper bound estimate because those air masses are contaminated by more ships and significant local pollution. These bounds are represented by $a-b$ or $a \ldots b$ with $a$ and $b$ showing lower and upper bounds, respectively. For $\mathrm{NO}_{\mathrm{x}}, \mathrm{SO}_{2}, \mathrm{PM}_{2.5}$, and $\mathrm{EBC}$, the cumulative concentration can be defined by

$S_{j, k}=\sum\left(C_{j, k}-C_{10 \%}\right)$,

where $S_{j, k}$ is the cumulative concentration for a species of interest in cluster $j$ (s for ships upstream and ns for no ships 
Table 8. Percent contribution of shipping to total pollution $\left(F_{k}\right)$, defined for wind sector $k$ (cws for clear wind sectors, upper bound, and aws for all wind sectors, lower bound).

\begin{tabular}{lllllll}
\hline Site & Estimate & $\mathrm{NO}_{\mathrm{x}}(\%)$ & $\mathrm{O}_{3}(\%)$ & $\mathrm{SO}_{2}(\%)$ & $\mathrm{PM}_{2.5}(\%)$ & $\mathrm{EBC}(\%)$ \\
\hline Cape Dorset & $\left(F_{\text {aws }}, F_{\mathrm{cws}}\right)$ & $12.9 \ldots 17.5$ & $16.2 \ldots 18.1$ & $16.9 \ldots 18.3$ & $19.5 \ldots 31.7$ & \\
Resolute & $\left(F_{\text {aws }}, F_{\mathrm{cws}}\right)$ & $1.0 \ldots 7.2$ & $2.9 \ldots 4.8$ & $5.5 \ldots 10.0$ & $6.5 \ldots 7.2$ & $4.3 \ldots 9.8$ \\
\hline
\end{tabular}

Table 9. Percent contribution of shipping to total ozone titration $\left(\mathrm{FT}_{k}\right)$ and ozone enhancement $\left(\mathrm{FE}_{k}\right)$; subscripts as in caption of Table 8 .

\begin{tabular}{lll}
\hline Site & Estimate & $\mathrm{O}_{3}(\%)$ \\
\hline Cape Dorset & $\left(\mathrm{FT}_{\mathrm{aws}}, \mathrm{FT}_{\mathrm{cws}}\right)$ & $15.7 \ldots 20.1$ \\
Cape Dorset & $\left(\mathrm{FE}_{\mathrm{aws}}, \mathrm{FE}_{\mathrm{cws}}\right)$ & $15.8 \ldots 18.5$ \\
Resolute & $\left(\mathrm{FT}_{\mathrm{aws}}, \mathrm{FT}_{\mathrm{cws}}\right)$ & $3.7 \ldots 7.1$ \\
Resolute & $\left(\mathrm{FE}_{\mathrm{aws}}, \mathrm{FE}_{\mathrm{cws}}\right)$ & $2.1 \ldots 3.5$ \\
\hline
\end{tabular}

upstream), and $k$ is the subcluster (cws for clear wind sectors, lower bound, and aws for all wind sectors, upper bound), $C_{j, k}$ is concentration, and $C_{10 \%}$ is the lowest $10 \%$ (decile $D_{1}$ ) concentration for the entire data set. The decile $D_{1}$ is a proxy for background concentration.

Since there are seasonal variations in $\mathrm{O}_{3}$, a suitable proxy for background mixing ratio is the daily median mixing ratio. There are many ways to define cumulative pollution by ozone. One approach is to consider pollution as any perturbation from the median,

$S_{j, k}=\sum\left|C_{j, k}-C_{50 \%}\right|$

with similar notation except for $C_{50} \%$ representing the daily median mixing ratio for all wind sectors. Note that with this definition, ozone reduction due to titration is also viewed as a perturbation. Thus, the percent contribution of shipping to total pollution can be calculated by

$F_{k}=100 \times \frac{S_{\mathrm{s}, k}}{S_{\mathrm{ns}, k}+S_{\mathrm{s}, k}}$.

Alternatively, cumulative pollution by ozone can be separated to pollution due to titration $\left(\mathrm{ST}_{j, k}\right)$, for when the mixing ratios are below daily median, and enhancement $\left(\mathrm{SE}_{j, k}\right)$, for when the mixing ratios are above daily median. These can be defined by

$$
\begin{aligned}
& \mathrm{ST}_{j, k}=\sum\left(C_{50 \%}-C_{j, k}\right), \\
& \mathrm{SE}_{j, k}=\sum\left(C_{j, k}-C_{50 \%}\right) .
\end{aligned}
$$

Thus, the percent contribution of shipping to ozone titration or enhancement can be calculated as

$\mathrm{FT}_{k}=100 \times \frac{\mathrm{ST}_{\mathrm{s}, k}}{\mathrm{ST}_{\mathrm{ns}, k}+\mathrm{ST}_{\mathrm{s}, k}}$,
$\mathrm{FE}_{k}=100 \times \frac{\mathrm{SE}_{\mathrm{s}, k}}{\mathrm{SE}_{\mathrm{ns}, k}+\mathrm{SE}_{\mathrm{s}, k}}$.

Figure 15 and Tables 8 and 9 show the results of the cumulative pollution analysis graphically and numerically. The sample size for each air mass cluster is provided in Table 3. The cumulative concentrations indicate that the impact of other sources of pollution is about 1 order of magnitude higher than that of shipping. The cumulative shipping pollution for all species is higher in Cape Dorset than Resolute.

In our analysis for black carbon in Resolute, we find that EBC constitutes $1.3-9.7 \%$ of total $\mathrm{PM}_{2.5}$ mass. Some airborne plume intercept studies report this fraction for ships (burning heavy fuel oil operating at $100 \%$ engine loading) as $21.4 \%$ (Petzold et al., 2008), $23.3 \%$ (Lack et al., 2009), and $5.8 \%$ (Lack et al., 2011). Some frequent vessels in the Canadian Arctic, such as the Amundsen coast guard icebreaker, burn distillate fuels as opposed to heavy fuel oil. In addition, we suggest that after aerosol processing over many hours (our case), hydrophilic components of total particulate emissions grow, acquiring more mass, but the EBC components (mainly hydrophobic) do not. These facts justify our slightly lower mass fractions of EBC at the site.

Cumulative percent ship contribution to pollution for all species is greater in Cape Dorset, justified by a longer shipping season and a shorter distance between ships, particularly at anchoring position, and the monitoring station. We estimate the percent ship contribution $(F)$ to $\mathrm{NO}_{\mathrm{x}}, \mathrm{O}_{3}, \mathrm{SO}_{2}$, and $\mathrm{PM}_{2.5}$ as 12.9-17.5 \%, 16.2-18.1\%, 16.9-18.3\%, and 19.5$31.7 \%$ for Cape Dorset. Similar estimates for $\mathrm{NO}_{\mathrm{x}}, \mathrm{O}_{3}, \mathrm{SO}_{2}$, $\mathrm{PM}_{2.5}$, and EBC are 1.0-7.2\%, 2.9-4.8\%, 5.5-10.0\%, 6.6$7.2 \%$, and $4.3-9.8 \%$ in Resolute.

\section{Conclusions and future work}

In an effort to characterize air quality in two communities of the Canadian Arctic during the high shipping season, we have measured surface concentrations of $\mathrm{NO}_{\mathrm{x}}, \mathrm{O}_{3}, \mathrm{SO}_{2}$, and $\mathrm{PM}_{2.5}$ in Cape Dorset and Resolute, Nunavut, for the complete 2013 shipping season. A particular focus of the study was the relative impact of pollution due to shipping vs. other sources, near high shipping traffic zones adjacent to the Arctic Bridge and the Northwest Passage.

For both sites, higher $\mathrm{NO}_{\mathrm{x}}$ concentrations were dominated by local emissions. The $90 \%$ confidence interval for mean 
difference between non-ship- and ship-influenced air masses showed higher $\mathrm{NO}_{\mathrm{x}}$ concentrations up to $0.7-0.9 \mathrm{ppb}$ in Cape Dorset and 1.0-1.1 ppb in Resolute. In Cape Dorset, local emissions were responsible for $\mathrm{O}_{3}$ titration, but in Resolute, both titration and photochemical enhancement governed ozone levels. Overall, the influence of shipping on $\mathrm{O}_{3}$ mixing ratios was that of enhancement by up to $4.6-4.7 \mathrm{ppb}$ in Cape Dorset and 2.5-2.7 ppb in Resolute, persistent for ship plumes up to $72 \mathrm{~h}$ of age. $\mathrm{PM}_{2.5}$ concentrations were consistently higher for ship-influenced air masses by up to $1.8-1.9 \mu \mathrm{g} \mathrm{m}^{-3}$ in Cape Dorset and $0.5-0.6 \mu \mathrm{g} \mathrm{m}^{-3}$ in Resolute. Unlike ozone, high $\mathrm{PM}_{2.5}$ concentrations in ship plumes were persistent only up to $24 \mathrm{~h}$, with deposition reducing the concentrations in older plumes. High-concentration $\mathrm{SO}_{2}$ pollution events were rare and episodic so that no statistically significant statement could be made regarding the effect of shipping on high $\mathrm{SO}_{2}$ concentrations. In addition, our instrument had a lower detection limit for $\mathrm{SO}_{2}$ that was above the current background level.

The high-resolution AQHI primarily followed seasonal $\mathrm{O}_{3}$ levels and was higher for Cape Dorset than Resolute. Shipinfluenced air masses consistently exhibited an increase of 0.1-0.3 in AQHI compared to no ship-influenced air masses. This difference is small with existing low levels of shipping traffic in the Arctic, but it can be expected to intensify with increasing traffic.

Lower and upper bounds in cumulative pollution were estimated by grouping air masses that arrived at the sites from clear wind sectors, dominantly influenced by ship pollution, and all wind sectors, influenced by ship and local pollution. We estimate the percent ship contribution to $\mathrm{NO}_{\mathrm{x}}, \mathrm{O}_{3}, \mathrm{SO}_{2}$, and $\mathrm{PM}_{2.5}$ as $12.9-17.5 \%, 16.2-18.1 \%, 16.9-18.3 \%$, and 19.5-31.7 \% for Cape Dorset and 1.0-7.2 \%, 2.9-4.8 \%, 5.5$10.0 \%$, and 4.3-9.8\% for Resolute during the 2013 shipping season. Additional measurements in Resolute suggested that percent ship contribution to black carbon was $4.3-9.8 \%$ and that black carbon constituted $1.3-9.7 \%$ of total $\mathrm{PM}_{2.5}$ mass in ship plumes.

One limitation of these estimates is the use of trajectories as opposed to plume dispersion modeling. Plume dispersion modeling for our purposes was virtually impractical since it would have required plume dispersion simulations for each ship at short time intervals for the entire shipping season, which was an immense computational calculation and beyond the scope of our analysis. Nevertheless, the order of magnitude and the comparative results between the two sites are relevant and informative to this field of research.

Continued air quality monitoring in the above sites during future shipping seasons would improve the statistics in our analysis as well as characterize repeating seasonal patterns in air quality due to shipping, local pollution, and long-range transport.

\section{Copyright statement}

The works published in this journal are distributed under the Creative Commons Attribution 3.0 License. This license does not affect the Crown copyright work, which is re-usable under the Open Government Licence (OGL). The Creative Commons Attribution 3.0 License and the OGL are interoperable and do not conflict with, reduce or limit each other.

${ }^{\circledR}$ Crown copyright 2014

Acknowledgements. The authors are indebted to Mark Gordon for assisting in the calibration and installation of the monitoring stations, the help of Andrew Elford for setting up the data transfer protocol from the Arctic, Colin Gibson (Cape Dorset), Wayne Davidson (Resolute), and Steven Laszlo (Toronto) for the routine maintenance of the monitoring stations, the help of Daniel Veber for instrumentation of the particle measurement equipment in Resolute, the help of Jacinthe Racine for running the Canadian Meteorological Center trajectory model for comparison with HYSPLIT model, and also the assistance of David Niemi for providing land-based emission inventories in the north. We also acknowledge the expert reviews of the manuscript by Lynn Lyons and Wanmin Gong, and the useful discussions with Richard Leaitch. Authors acknowledge collaboration with John Ogren at NOAA/ESRL on the use of data collection software for the optical instruments measuring equivalent black carbon. The funding support and cooperation among various branches, directorates, and divisions within Environment Canada are acknowledged:Environmental Stewardship Branch, Energy and Transportation Directorate, Transportation Division; Science and Technology Branch, Atmospheric Science and Technology Directorate, Air Quality Research Division and Climate Research Division; and Meteorological Service of Canada, Weather and Environmental Prediction and Services Directorate, National Prediction Operations Division.

Edited by: R. Ebinghaus

\section{References}

Bond, T. C., Anderson, T. L., and Campbell, D.: Calibration and intercomparison of filter-based measurements of visible light absorption by aerosols, Aerosol Sci. Tech., 30, 582-600, doi:10.1080/027868299304435, 1999.

Brigham, L., McCalla, R., Cunningham, E., Barr, W., Vanderzaag, D., Chircop, A., Santos-Pedro, V., MacDonald, R. Harder, S., Ellis, B., Snyder, J., Huntington, H., Skjoldal, H., Williams, M., Wojhan, T., and Falkingham, J.: Arctic Marine Shipping Assessment, Report, Arctic Council, Troms $\varnothing$, Norway, available at: http://library.arcticportal.org/1400/ (last access: 3 March 2014), 2009.

Browse, J., Carslaw, K. S., Schmidt, A., and Corbett, J. J.: Impact of future Arctic shipping on high-latitude black carbon deposition, Geophys. Res. Lett., 40, 4459-4463, doi:10.1002/grl.50876, 2013. 
Bulletin: Ship Safety Bulletin: New regulations for vessel air emissions, ship to ship transfer of oil, and greywater, Bulletin 06/2013, Transport Canada, Marine Safety and Security, Tower C, Place de Ville, 10th Floor, 330 Sparks Street, Ottawa, ON K1A 0N8, available at: http://www.tc.gc.ca/media/documents/ marinesafety/SSB-06-2013E.pdf (last access: 10 July 2014), 2013.

Capaldo, K. P. and Pandis, S. N.: Dimethylsulfide chemistry in the remote marine atmosphere: evaluation and sensitivity analysis of available mechanisms, J. Geophys. Res.-Atmos., 102, 2325123267, doi:10.1029/97JD01807, 1997.

Cappa, C. D., Williams, E. J., Lack, D. A., Buffaloe, G. M., Coffman, D., Hayden, K. L., Herndon, S. C., Lerner, B. M., Li, S.M., Massoli, P., McLaren, R., Nuaaman, I., Onasch, T. B., and Quinn, P. K.: A case study into the measurement of ship emissions from plume intercepts of the NOAA ship Miller Freeman, Atmos. Chem. Phys., 14, 1337-1352, doi:10.5194/acp-14-13372014, 2014.

City-Data: City Data, available at: http://www.city-data.com (last access: 18 March 2014), 2011.

Climate: Historical Climate Data, available at: http://climate. weather.gc.ca (last access: 14 November 2014), 2014.

Corbett, J. J., Lack, D. A., Winebrake, J. J., Harder, S., Silberman, J. A., and Gold, M.: Arctic shipping emissions inventories and future scenarios, Atmos. Chem. Phys., 10, 9689-9704, doi:10.5194/acp-10-9689-2010, 2010a.

Corbett, J. J., Winebrake, J. J., and Green, E. H.: An assessment of technologies for reducing regional short-lived climate forcers emitted by ships with implications for Arctic shipping, Future Science, 1, 207-225, doi:10.4155/cmt.10.27, 2010 b.

Derksen, C., Smith, S. L., Sharp, M., Brown, L., Howell, S., Copland, L., Mueller, D. R., Gauthier, Y., Fletcher, C., Tivy, A., Bernier, M., Bourgeois, J., Brown, R., Burn, C. R., Duguay, C., Kushner, P., Langlois, A., Lewkowicz, A. G., Royer, A., and Walker, A.: Variability and change in the Canadian Cryosphere, Climatic Change, 115, 59-88, doi:10.1007/s10584-012-0470-0, 2012.

Draxler, R. R. and Hess, G. D.: Description of the HYSPLIT 4 modeling system, Report NOAA Technical Memorandum ERL ARL244, Air Resources Laboratory, Silver Spring, Maryland, available at: www.arl.noaa.gov/documents/reports/arl-224.pdf (last access: 17 March 2014), 2010.

Draxler, R. R., Stunder, B., Rolph, G., Stein, A., and Taylor, A.: HYSPLIT 4 user's guide, Report, Air Resources Laboratory, Silver Spring, Maryland, available at: www.arl.noaa. gov/documents/reports/hysplit_user_guide.pdf (last access: 17 March 2014), 2013.

Eckhardt, S., Hermansen, O., Grythe, H., Fiebig, M., Stebel, K., Cassiani, M., Baecklund, A., and Stohl, A.: The influence of cruise ship emissions on air pollution in Svalbard - a harbinger of a more polluted Arctic?, Atmos. Chem. Phys., 13, 8401-8409, doi:10.5194/acp-13-8401-2013, 2013.

Granier, C., Niemeier, U., Jungclaus, J. H., Emmons, L., Hess, P., Lamarque, J.-F., Walters, S., and Brasseur, G. P.: Ozone pollution from future ship traffic in the Arctic northern passages, Geophys. Res. Lett., 33, 1-5, doi:10.1029/2006GL026180, 2006.

Helmig, D., Oltmans, S. J., Carlson, D., Lamarque, J.-F., Jones, A., Labuschagne, C., Anlauf, K., and Hayden, K.: A review of sur- face ozone in the polar regions, Atmos. Environ., 41, 5138-5161, doi:10.1016/j.atmosenv.2006.09.053, 2007.

Hudson, E., Aihoshi, D., Gaines, T., Simard, G., and Mullock, J.: The weather of Nunavut and the Arctic, Report LAWM-Arctic-EN, NAV Canada, 77 Metcalfe Street, Ottawa, ON K1P 5L6, Canada, available at: http://www.navcanada.ca/EN/media/Publications/Local\% 20Area\%20Weather\%20Manuals/LAWM-Arctic-EN.pdf (last access: 21 June 2014), 2001.

IMO: In Proposal to Designate an Emission Control Area for Nitrogen Oxides, Sulphur Oxides and Particulate Matter. Submitted by the United States and Canada, Report IMO MPEC 59, 2009, International Maritime Organization, available at: http://www.epa. gov/nonroad/marine/ci/mepc-59-eca-proposal.pdf (last access: 6 August 2014), 2009.

Jalkanen, J.-P., Brink, A., Kalli, J., Pettersson, H., Kukkonen, J., and Stipa, T.: A modelling system for the exhaust emissions of marine traffic and its application in the Baltic Sea area, Atmos. Chem. Phys., 9, 9209-9223, doi:10.5194/acp-9-9209-2009, 2009.

Jalkanen, J.-P., Johansson, L., Kukkonen, J., Brink, A., Kalli, J., and Stipa, T.: Extension of an assessment model of ship traffic exhaust emissions for particulate matter and carbon monoxide, Atmos. Chem. Phys., 12, 2641-2659, doi:10.5194/acp-12-26412012, 2012.

Jeffries, M. O., Richter-Menge, J. A., and Overland, J. E.: Arctic Report Card, Report, NOAA, available at: http://www.arctic. noaa.gov/reportcard (last access: 17 April 2014), 2013.

Judek, S., Stieb, D., Jovic, B., and Edwards, B.: Air Quality Benefits Assessment Tool (AQBAT), User Guide, Version 2 (Draft), March 2012, Healthy Environments and Consumer Safety Branch (HECSB), Health Canada, 2012.

Lack, D. A. and Corbett, J. J.: Black carbon from ships: a review of the effects of ship speed, fuel quality and exhaust gas scrubbing, Atmos. Chem. Phys., 12, 3985-4000, doi:10.5194/acp-12-39852012, 2012.

Lack, D. A., Corbett, J. J., Onasch, T. B., Lerner, B., Massoli, P., Quinn, P. K., Covert, T. S. B. D. S., Coffman, D., Sierau, B., Herndon, S., Allan, J., Baynard, T., Lovejoy, E., Ravishankara, A. R., and Williams, E.: Particulate emissions from commercial shipping: chemical, physical, and optical properties, J. Geophys. Res.-Atmos., 114, D00F04, doi:10.1029/2008JD011300, 2009.

Lack, D. A., Cappa, C. D., Langridge, J., Bahreini, R., Buffaloe, G., Brock, C., Cerully, K., Coffman, D., Hayden, K., Holloway, J., Lerner, B., Massoli, P., Li, S.-M., McLaren, R., Middlebrook, A. M., Moore, R., Nenes, A., Nuaaman, I., Onasch, T. B., Peischl, J., Perring, A., Quinn, P. K., Ryerson, T., Schwartz, J. P., Spackman, R., Wofsy, S. C., Worsnop, D., Xiang, B., and Williams, E.: Impact of fuel quality regulation and speed reductions on shipping emissions: implications for climate and air quality, Environ. Sci. Technol., 45, 9052-9060, doi:10.1021/es2013424, 2011.

Law, K. S. and Stohl, A.: Arctic air pollution: origins and impacts, Science, 315, 1537-1540, doi:10.1126/science.1137695, 2007.

Lee, J.-G., Han, J., and Whang, K.-Y.: Trajectory clustering: a partition-and-group framework, Proceedings of the 2007 ACM SIGMOD International Conference on Management of Data, 
Beijing, China, available at: http://dl.acm.org/citation.cfm?id= 1247546 (last access: 15 January 2014), 2007.

Novelli, P. C., Masarie, K. A., and Lang, P. M.: Distributions and recent changes of carbon monoxide in the lower troposphere, J. Geophys. Res.-Atmos., 103, 19015-19033, doi:10.1029/98JD01366, 1998.

NPRI: National Pollutants Release Inventory (NPRI) Nunavut and Northwest Territories, available at: http://www.ec.gc.ca/inrpnpri/default.asp?lang=en\&n=0EC58C98- (last access: 22 January 2014), 2011.

O'Dowd, C. D., Smith, M. H., Consterdine, I. E., and Lowe, J. A.: Marine aerosol, sea-salt, and the marine sulphur cycle: a short review, Atmos. Environ., 31, 73-80, doi:10.1016/S13522310(96)00106-9, 1997.

Ogren, J. A.: Comment on "Calibration and Intercomparison of Filter-Based Measurements of Visible Light Absorption by Aerosols", Aerosol Sci. Tech., 44, 589-591, doi:10.1080/02786826.2010.482111, 2010.

Ogren, J. A., Wendell, J., Sheridan, P. J., Hageman, D., and Jefferson, A.: Continuous light absorption photometer performance, ASR Science Team Meeting, Potomac, Md, 18-21 March 2013, available at: http://asr.science.energy.gov/meetings/stm/posters/ view?id=781 (last access: 19 August 2014), 2013.

Petzold, A., Hasselbach, J., Lauer, P., Baumann, R., Franke, K., Gurk, C., Schlager, H., and Weingartner, E.: Experimental studies on particle emissions from cruising ship, their characteristic properties, transformation and atmospheric lifetime in the marine boundary layer, Atmos. Chem. Phys., 8, 2387-2403, doi:10.5194/acp-8-2387-2008, 2008.

Petzold, A., Weingartner, E., Hasselbach, J., Lauer, P., Kurok, C., and Fleischer, F.: Physical properties, chemical composition, and cloud forming potential for particulate emissions from a marine diesel engine at various load conditions, Environ. Sci. Technol., 44, 3800-3805, doi:10.1021/es903681z, 2010.

Petzold, A., Lauer, P., Fritsche, U., Hasselbach, J., Lichtenstern, M., Schlager, H., and Fleischer, F.: Operation of marine diesel engines on biogenic fuels: modification of emissions and resulting climate effects, Environ. Sci. Technol., 45, 10394-10400, doi:10.1021/es2021439, 2011.

Pizzolato, L., Howell, S. E. L., Derksen, C., Dawson, J., and Copland, L.: Changing sea ice conditions and marine transportation activity in Canadian Arctic waters between 1990 and 2012, Clim. Change, 123, 161-173, doi:10.1007/s10584-013-1038-3, 2014.

Quinn, P. K., Bates, T. S., Baum, E., Doubleday, N., Fiore, A. M., Flanner, M., Fridlind, A., Garrett, T. J., Koch, D., Menon, S., Shindell, D., Stohl, A., and Warren, S. G.: Short-lived pollutants in the Arctic: their climate impact and possible mitigation strategies, Atmos. Chem. Phys., 8, 1723-1735, doi:10.5194/acp8-1723-2008, 2008.

Rompkey, W. and Cochrane, E.: The coast guard in Canada's Arctic: interim Report, Technical report, Senate of Canada, Standing Senate and Committee on Fisheries and Oceans, Fourth Report, available at: http://www.parl.gc.ca/Content/SEN/ Committee/392/fish/rep/rep04jun08-e.pdf (last access: 7 April 2014), 2008.

Seabrook, J. A., Whiteway, J., Staebler, R. M., Bottenheim, J. W., Komguem, L., Gray, L. H., Barber, D., and Asplin, M.: LIDAR measurements of Arctic boundary layer ozone depletion events over the frozen Arctic Ocean, J. Geophys. Res.-Atmos., 116, 18, doi:10.1029/2011JD016335, 2011.

Seinfeld, J. H. and Pandis, S. N.: Atmospheric Chemistry and Physics from Air Pollution to Climate Change, 2nd edn., 209211, John Wiley \& Sons, Inc., Hoboken, New Jersey, USA, 2006.

Sharma, S., Barrie, L. A., Plummer, D., McConnell, J. C., Brickell, P. C., Levasseur, M., Gosselin, M., and Bates, T. S.: Flux estimation of oceanic dimethyl sulfide around North America, J. Geophys. Res.-Atmos., 104, 21327-21342, doi:10.1029/1999JD900207, 1999.

Sharma, S., Lavoue, D., Cachier, H., Barrie, L. A., and Gong, S. L.: Long term trends of the black carbon concentrations in the Canadian Arctic, J. Geophys. Res.-Atmos., 109, D15203, doi:10.1029/2003JD004331, 2004.

Sharma, S., Andrews, E., Barrie, L. A., Orgen, J. A., and Lavoué, D.: Variations and sources of the equivalent black carbon in the high Arctic revealed by long-term observations at Alert and Barrow: 1989-2003, J. Geophys. Res.-Atmos., 111, D14208, doi:10.1029/2005JD006581, 2006.

Sharma, S., Chan, E., Ishizawa, M., Toom-Sauntry, D., Gong, S. L., Li, S. M., Tarasick, D. W., Leaitch, W. R., Norman, A., Quinn, P. K., Bates, T. S., Levasseur, M., Barrie, L. A., and Maenhaut, W.: Influence of transport and ocean ice extent on biogenic aerosol sulfur in the Arctic atmosphere, J. Geophys. Res.Atmos., 117, D12209, doi:10.1029/2011JD017074, 2012.

Shindell, D. T., Chin, M., Dentener, F., Doherty, R. M., Faluvegi, G., Fiore, A. M., Hess, P., Koch, D. M., MacKenzie, I. A., Sanderson, M. G., Schultz, M. G., Schulz, M., Stevenson, D. S., Teich, H., Textor, C., Wild, O., Bergmann, D. J., Bey, I., Bian, H., Cuvelier, C., Duncan, B. N., Folberth, G., Horowitz, L. W., Jonson, J., Kaminski, J. W., Marmer, E., Park, R., Pringle, K. J., Schroeder, S., Szopa, S., Takemura, T., Zeng, G., Keating, T. J., and Zuber, A.: A multi-model assessment of pollution transport to the Arctic, Atmos. Chem. Phys., 8, 5353-5372, doi:10.5194/acp-8-5353-2008, 2008.

Sillman, S.: The relation between ozone, $\mathrm{NO}_{\mathrm{x}}$ and hydrocarbons in urban and polluted rural environments, Atmos. Environ., 33, 1821-1845, doi:10.1016/S1352-2310(98)00345-8, 1999.

Sirois, A. and Barrie, L. A.: Arctic lower tropospheric aerosol trends and composition at Alert, Canada: 1980-1995, J. Geophys. Res.Atmos., 104, 11599-11618, doi:10.1029/1999JD900077, 1999.

Smith, L. C. and Stephenson, S. R.: New Trans-Arctic shipping routes navigable by mid century, P. Natl. Acad. Sci. USA, 110, 4871-4872, doi:10.1073/pnas.1214212110, 2013.

Stephenson, S. R., Smith, L. C., and Agnew, J. A.: Divergent longterm trajectories of human access to the Arctic, Nature Clim. Change, 1, 156-160, doi:10.1038/nclimate1120, 2011.

Stieb, D. M., Burnett, R. T., Smith-Doiron, M., Brion, O., Shin, H. H., and Economou, V.: A new multipollutant, nothreshold air quality health index based on short-term associations observed in daily time-series analyses, J. Air Waste Manage., 58, 435-450, doi:10.3155/1047-3289.58.3.435, 2008.

Stohl, A.: Computation, accuracy and applications of trajectories - a review and bibliography, Atmos. Environ., 32, 947-966, doi:10.1016/S1352-2310(97)00457-3, 1998.

Stohl, A., Klimont, Z., Eckhardt, S., Kupiainen, K., Shevchenko, V. P., Kopeikin, V. M., and Novigatsky, A. N.: Black carbon in the Arctic: the underestimated role of gas flaring 
and residential combustion emissions, Atmos. Chem. Phys., 13, 8833-8855, doi:10.5194/acp-13-8833-2013, 2013.

Sulphur: Sulphur in liquid fuels 2009, Annual Report EN116/2009E-PDF, Oil, Gas and Alternative Energy Division, Fuels Section, Environment Canada, Place Vincent Massey, 12th floor, Gatineau, QC K1A 0H3, available at: http://www.ec.gc.ca/Publications/default.asp?lang=En\&xml= 0B7E8337-572E-4980-B82D-E8E92334403D (last access: 27 December 2013), 2012.

Tivy, A., Howell, S. E. L., Alt, B., McCourt, S., Chagnon, R., Crocker, G., Carrieres, T., and Yackel, J. J.: Trends and variability in summer sea ice cover in the Canadian Arctic based on the Canadian Ice Service Digital Archive, 19602008 and 1968-2008, J. Geophys. Res.-Oceans, 116, C03007, doi:10.1029/2009JC005855, 2011.

TÜV: Translation of the report on the suitability test of the multi-component air measuring system Airpointer of the company Recordum Messtechnik $\mathrm{GmBH}$ for the components NO, $\mathrm{NO}_{2}, \mathrm{NO}_{\mathrm{x}}, \mathrm{SO}_{2}, \mathrm{O}_{3}$, and CO, Report 936/21209700/A, TÜV Rheinland IMMISSIONSSCHUTZ UND ENERGIESYSTEME GmBH, Cologne, Germany, 2009.
Walpole, R. E., Myers, R. H., Myers, S. L., and Ye, K.: Probability \& Statistics for Engineers and Scientists, 7th edn., 246-53, Prentice-Hall, Inc., Upper Saddle River, NJ 07458, 2002.

Wang, S. C. and Flagan, R. C.: Scanning electrical mobility spectrometer, Aerosol Sci. Tech., 13, 230-240, doi:10.1080/02786829008959441, 1990.

Winther, M., Christensen, J. H., Plejdrup, M. S, Ravn, E. S., Eriksson, Ó. F., and Kristensen, H. O.: Emission inventories for ships in the Arctic based on satellite sampled AIS data, Atmos. Environ., 91, 1-14, doi:10.1016/j.atmosenv.2014.03.006, 2014.

Yin, F. and Seinfeld, D. G. J. H.: Photooxidation of dimethyl sulfide and dimethyl disulfide. I: Mechanism development, J. Atmos. Chem., 11, 309-364, doi:10.1007/BF00053780, 1990.

Zhan, J., Gao, Y., Li, W., Chen, L., Lin, H., and Lin, Q.: Effects of ship emissions on summertime aerosols at $\mathrm{Ny}$ Alesund in the Arctic, Atmos. Pollut. Res., 5, 500-510, doi:10.5094/APR.2014.059, 2014. 